\title{
APLIKASI FOSFAT PADA PROSES EKSTRAKSI TEH HIJAU UNTUK MINUMAN TEH HIJAU SIAP MINUM
}

\author{
[Phosphate Application in Green Tea Extraction Process for \\ Ready To Drink (RTD) Green Tea]
}

\author{
Rima Hidayati ${ }^{1)}$, Nuri Andarwulan ${ }^{2,3) \star}$, dan Dian Herawati ${ }^{2,3)}$ \\ 1) Program Studi Magister Teknologi Pangan, Sekolah Pascasarjana, IPB University, Bogor \\ 2) Departemen Ilmu dan Teknologi Pangan, Fakultas Teknologi Pertanian, IPB University, Bogor \\ 3) South East Asian Food and Agricultural Science and Technology (SEAFAST) Center, IPB University, Bogor
}

Diterima 5 Agustus 2020 / Disetujui 22 Maret 2021

\begin{abstract}
Color is one of quality parameters that affects consumer intention to purchase ready to drink (RTD) green tea. Consumers expect RTD green tea to have yellow greenish color, however the color becomes brown and darker during the shelf life. This study aimed to evaluate the effect of phosphate mix addition to water prior to green tea leaves extraction on $\mathrm{pH}$, color, and the tannin in tea extract, pre-RTD, and RTD during incubation period at $60^{\circ} \mathrm{C}$ for 2 days. The pre-RTD contained tea extract, sugar, and ascorbic acid. Addition of sodium bicarbonate was done in pre-RTD to obtain RTD with $p H$ of $6.1 \pm 0.2$. The type of phosphate used was sodium acid pyrophosphate (SAPP) and phosphoric acid. The concentrations of SAPP were 650 and $1300 \mathrm{mg} / \mathrm{L}$, while those of phosphoric acid were 125, 250, and $500 \mathrm{mg} / \mathrm{L}$. The total phosphorous added from the combination of SAPP and phosphoric acid was 221-521 mg/L. Meanwhile, green tea extracted without phosphate was used as a control. The results showed that phosphate addition to water prior to green tea extraction caused decrease in $\mathrm{pH}$ of tea extract from 5.83 \pm 0.18 to 2.8-3.8, decrease in browning intensity, and reduced tannin degradation during the incubation period. Sugar and ascorbic acid added to the tea extract resulted in $\mathrm{pH}$ in all samples $<4.0$ and maintained the lightness of the pre-RTD. Phosphate application was not able to retain the color of RTD after incubation period. This study showed that addition of phosphorous as a combination of SAPP and phosphoric acid to water at concentrations of 221-521 $\mathrm{mg} / \mathrm{L}$ prior to green tea extraction had positive impact in reducing browning intensity of RTD green tea with $\mathrm{pH}$ of lower than 4.0 .
\end{abstract}

Keywords: color, green tea extraction, $\mathrm{pH}$, phosphate, RTD

\begin{abstract}
ABSTRAK
Warna merupakan salah satu parameter mutu yang memengaruhi keputusan konsumen untuk membeli minuman teh hijau siap minum. Konsumen memiliki ekspektasi bahwa teh hijau siap minum berwarna kuning kehijauan, tetapi kenyataannya selama penyimpanan warnanya berubah menjadi cokelat dan lebih gelap. Penelitian ini bertujuan mengevaluasi efek penambahan fosfat pada air pengekstrak sebelum proses ekstraksi teh hijau terhadap $\mathrm{pH}$, warna, dan tanin ekstrak teh, pre-ready to drink (pre-RTD) dan RTD hingga masa inkubasi pada suhu $60^{\circ} \mathrm{C}$ selama 2 hari. Pre-RTD terdiri dari ekstrak teh, gula, dan asam askorbat. Penambahan natrium bikarbonat pada pre-RTD dilakukan untuk mendapatkan RTD dengan $\mathrm{pH}$ $6,1 \pm 0,2$. Jenis fosfat yang digunakan yaitu sodium acid pyrophosphate (SAPP) dan asam fosfat. Konsentrasi SAPP yang digunakan yaitu 650 dan $1300 \mathrm{mg} / \mathrm{L}$, sedangkan konsentrasi asam fosfat yang digunakan yaitu 125,250 , dan $500 \mathrm{mg} / \mathrm{L}$. Jumlah fosfor yang diperoleh dari campuran SAPP dan asam fosfat tersebut yaitu 221-521 mg/L. Teh hijau yang diekstraksi tanpa fosfat disebut sebagai kontrol. Hasil penelitian menunjukkan penambahan fosfat pada air pengekstrak sebelum proses ekstraksi teh hijau dapat menurunkan $\mathrm{pH}$ ekstrak teh dari 5,83 $\pm 0,18$ menjadi 2,8-3,8, menurunkan intensitas pencokelatan, dan mengurangi degradasi tanin hingga setelah masa inkubasi. Gula dan asam askorbat yang ditambahkan pada ekstrak teh dapat membuat $\mathrm{pH}$ semua sampel $<4,0$ dan mempertahankan kecerahan pre-RTD. Aplikasi fosfat tidak dapat mempertahankan stabilitas warna RTD setelah masa inkubasi. Penelitian ini menunjukkan bahwa penambahan fosfor pada air pengekstrak dengan jumlah 221-521 mg/L yang berasal dari campuran SAPP dan asam fosfat sebelum proses ekstraksi teh hijau dapat memperlambat pencokelatan minuman teh hijau RTD yang memiliki pH di bawah 4,0.
\end{abstract}

Kata kunci: ekstraksi teh hijau, fosfat, pH, RTD, warna

Makalah pernah dipresentasikan pada Seminar Hasil Penelitian, Sekolah Pascasarjana, Institut Pertanian Bogor, 11 Juli 2020, Bogor *Penulis Korespondensi: E-mail: andarwulan@apps.ipb.ac.id 


\section{PENDAHULUAN}

Teh (Camellia sinensis) merupakan salah satu bahan penyegar yang banyak dikonsumsi oleh konsumen Indonesia. Data Kemendag (2015) menunjukkan teh memiliki pangsa pasar (product share) $30 \%$ dalam industri minuman lokal. Meningkatnya jumlah populasi muda di Indonesia yang memiliki banyak aktivitas namun waktu yang terbatas untuk menyiapkan teh, memacu pertumbuhan industri minuman teh siap minum (RTD). Penelitian Briawan et al. (2011) menyebutkan bahwa teh kemasan merupakan minuman yang paling disukai selain air putih oleh $13,8 \%$ remaja di Jakarta dan $26,8 \%$ remaja di Bandung.

Berdasarkan tingkat fermentasinya, teh dapat dikategorikan menjadi teh hijau, teh oolong, dan teh hitam (Chan et al., 2011). Teh hijau mengandung polifenol yang tinggi yang dapat berperan sebagai antioksidan sehingga dapat mencegah kanker (Forester dan Lambert, 2011). Kandungan epigallokatekin galat (EGCG) pada teh hijau juga dapat berperan sebagai anti bakteri, anti virus, serta melindungi dari hipertensi dan penyakit jantung (Pastoriza et al., 2017). Minuman teh hijau RTD dalam kemasan botol polyethylene terephthalate (PET) merupakan salah satu alternatif bagi konsumen untuk mengonsumsi dan mendapatkan manfaat kesehatan dari teh hijau.

Aspek sensori memegang peranan penting dalam pemilihan produk. Warna merupakan karakter sensori pertama yang dinilai oleh konsumen. Minuman teh hijau RTD diharapkan berwarna kehijauan atau kuning kehijauan, tanpa adanya warna kemerahan atau kecokelatan. Warna hijau pada daun teh dan ekstrak teh utamanya ditentukan oleh kandungan klorofil dan rasio klorofil A (hijau gelap) dengan klorofil $B$ (hijau kekuningan) (Chaturvedula dan Prakash, 2011). Faktanya, seiring bertambahnya waktu penyimpanan, warna RTD teh hijau berubah menjadi cokelat gelap. Pencokelatan selama penyimpanan pada minuman teh termasuk dalam pencokelatan non enzimatik, yang penyebab utamanya adalah autooksidasi dan perubahan struktur flavanol. EGCG dan flavonol merupakan senyawa fenolik pada teh hijau yang dapat menyebabkan reaksi pencokelatan jika dipanaskan (Dai et al., 2017). Katekin berwarna kuning saat dilarutkan dalam air dan warna kuning semakin cepat terlihat dengan meningkatnya $\mathrm{pH}$ air (Bark et al., 2011). EGCG dan epigalokatekin (EGC) juga berperan penting dalam perubahan warna dan rasa pada teh hijau selama proses penyimpanan. Semakin lama waktu penyimpanan, kandungan EGCG memiliki kecenderungan untuk menurun, dan penurunannya semakin signifikan saat minuman teh hijau RTD disimpan pada suhu tinggi dan terpapar cahaya. Penelitian Baek et al. (2021) menunjukkan teh hijau
RTD yang terpapar cahaya fluorensens selama penyimpanan mengalami degradasi EGCG yang lebih tinggi signifikan serta memiliki aroma/rasa yang berbeda signifikan saat dikemas dalam botol gelas tanpa pelindung cahaya dibandingkan teh hijau RTD yang dilapisi pelindung cahaya (alumunium foil) pada kemasannya. Bahan kemasan dengan kecepatan transmisi oksigen yang berbeda juga dapat memengaruhi stabilitas teh RTD, karena adanya hubungan antara permeabilitas oksigen dengan degradasi polifenol (Kim et al., 2011).

Pencegahan perubahan warna dapat dilakukan dengan mengurangi reaksi oksidasi, mengkelat logam, atau melindungi polifenol. Beberapa penelitian telah mengaplikasikan bahan tambahan pangan untuk mencegah reaksi pencokelatan pada minuman teh, diantaranya menggunakan asam sitrat dan asam askorbat (Wang et al., 2003). Penelitian Vuong et al. (2013) menyebutkan untuk meminimalisasi degradasi katekin dan memaksimalkan hasil ekstraksi, maka $\mathrm{pH}$ pada proses ekstraksi dijaga pada kondisi asam, yaitu kisaran $\mathrm{pH}$ 3,0-5,3. Semakin tinggi $\mathrm{pH}$, maka kandungan katekin utama (epikatekin (EC), ECG, EGC, EGCG) akan terdegradasi dan mengalami epimerisasi ( $\mathrm{Li}$ et al., 2012).

Salah satu bahan tambahan pangan yang sudah banyak digunakan untuk mecegah perubahan warna pangan adalah fosfat. Selain mencegah perubahan warna, fosfat memiliki fungsi diantaranya mencegah off-flavor (citarasa menyimpang) pada sayur dan buah. Fosfat dapat berperan sebagai penukar ion, sehingga membentuk kompleks yang larut dengan ion polivalen yang keberadaannya dapat mengganggu proses pengolahan pangan. Kemampuan membentuk kompleks dengan ion logam tidak bergantung dengan panjang rantai polifosfat, namun kekuatan kompleks akan semakin meningkat dengan meningkatnya panjang rantai (Ellinger, 2018).

Aplikasi fosfat pada proses ekstraksi teh telah dilakukan oleh Xu et al. (2010) dan Zimmermann dan Gleichenhagen (2011). Penelitian Xu et al. (2010) menunjukkan bahwa aplikasi fosfat dalam bentuk sodium heksametafosfat (SHMP) dapat mencegah kekeruhan dan pengendapan minuman teh selama penyimpanan. Aplikasi bufer fosfat pada $\mathrm{pH}$ 3,0 dan 4,8 saat proses ekstraksi teh juga dapat meningkatkan konsentrasi flavanol teh hingga 20\% (Zimmermann dan Gleichenhagen, 2011). Fosfat dalam bentuk sodium acid pyrophosphate (SAPP) telah diaplikasikan dalam penelitian Hasan (2017). Penelitian tersebut menunjukkan kombinasi antara (SAPP) dengan asam askorbat dapat mencegah kerusakan antioksidan pada ubi jalar ungu. Menurut Ellinger (2018), SAPP dapat mencegah pencokelatan kentang setelah dimasak. 
SAPP merupakan fosfat dalam bentuk dimer yang termasuk dalam bahan tambahan pangan (BTP) kategori pengatur keasaman, pengembang, dan sekuestran (FAO, 2019). Berdasarkan BPOM (2019), SAPP termasuk BTP kategori garam penstabil, penstabil, dan pengemulsi. Dalam $1 \%$ air, SAPP memiliki pH 3,7-5,0. Asam fosfat merupakan BTP yang memiliki fungsi sebagai pengatur keasaman. Jumlah maksimum konsumsi SAPP dan asam fosfat dalam sehari tanpa menimbulkan efek merugikan terhadap kesehatan dihitung dari nilai maximum tolerable daily intake (MTDI). Nilai MTDI senyawa fosfat sebesar $70 \mathrm{mg} / \mathrm{kg}$ berat badan sebagai total fosfor.

Penelitian ini bertujuan mengevaluasi pengaruh penambahan fosfat yang terdiri dari sodium acid pyrophosphate (SAPP) dan asam fosfat pada air pengekstrak sebelum proses ekstraksi teh hijau terhadap stabilitas warna, $\mathrm{pH}$, dan tanin teh hijau dengan berbagai formulasi. Pemilihan SAPP dan asam fosfat sebagai senyawa pengekstrak disebabkan kombinasi SAPP dan asam fosfat dapat menurunkan $\mathrm{pH}$ air pengekstrak hingga $\mathrm{pH}$ sekitar 3,0 , serta SAPP memiliki kemampuan untuk mengikat ion-ion logam dalam air yang keberadaannya dapat menurunkan aktivitas antioksidan polifenol. Formulasi yang dianalisis yaitu ekstrak teh hijau, ekstrak teh hijau yang ditambah gula dan asam askorbat (preRTD), serta pada ekstrak teh hijau yang mengandung gula, asam askorbat, dan natrium bikarbonat (RTD).

\section{BAHAN DAN METODE}

\section{Bahan}

Bahan yang digunakan dalam penelitian ini antara lain bahan utama daun teh hijau grade Pekoe (PT KBP Chakra, Indonesia), sodium acid pyrophosphate (SAPP) INS 450 (i) (Reephos Chemical, China), asam fosfat INS 338 (Megah Abadi Kimia, Indonesia), air reverse osmosis (RO), gula rafinasi grade R1 (PT Sugar Labinta, Indonesia), asam askorbat INS 300 (CSPC Weisheng Pharmaceutical, China), dan natrium bikarbonat INS 500 (ii) (Natural Soda, USA)

\section{Perhitungan jumlah fosfor}

Jumlah fosfor pada penelitian ini diperoleh berdasarkan perhitungan perbandingan berat atom (Ar) fosfor dengan berat molekul (Mr) masingmasing SAPP dan asam fosfat, yang kemudian dikalikan dengan konsentrasi masing-masing SAPP dan asam fosfat yang ditambahkan. Cara perhitungan jumlah fosfor tersebut dapat dilihat pada persamaan (1) dan (2). Total fosfor diperoleh dari jumlah fosfor pada SAPP dan asam fosfat. Fosfor (P) memiliki berat atom $31 \mathrm{~g} / \mathrm{mol}$. SAPP (INS 450 (i)) memiliki rumus kimia $\mathrm{Na}_{2} \mathrm{H}_{2} \mathrm{P}_{2} \mathrm{O}_{7}$, dengan berat molekul 221,94 $\mathrm{g} / \mathrm{mol}$. Rumus kimia asam fosfat atau asam ortofosfat (INS 338) adalah $\mathrm{H}_{3} \mathrm{PO}_{4}$ dengan berat molekul 97,994 $\mathrm{g} / \mathrm{mol}$. Berdasarkan cara perhitungan tersebut, jumlah fosfor yang digunakan sebagai larutan pengekstrak pada penelitian ini berkisar antara 221 hingga $521 \mathrm{mg} / \mathrm{L}$. Jumlah tersebut sudah sesuai dengan batas maksimum penggunaan fosfor pada minuman teh, yaitu maksimum 1300 $\mathrm{mg} / \mathrm{kg}$ (BPOM, 2019).

Jumlah Fosfor dalam SAPP=

$\frac{\text { Ar P }}{\text { Mr SAPP }} \times$ dosis SAPP

Jumlah Fosfor dalam Asam Fosfat=

$\frac{\operatorname{Ar} \mathrm{P}}{\text { Mr asam fosfat }} \times$ dosis asam fosfat ................... (2)
Ekstraksi teh hijau (Xu et al., 2010 dengan
modifikasi)

Daun teh hijau $5 \mathrm{~g}$ diekstraksi dengan larutan pengekstrak yang terdiri dari air yang sudah diproses osmosis terbalik/reverse osmosis (RO) $150 \mathrm{~g}$ dengan atau tanpa campuran fosfat pada hot plate stirrer (ThermoScientific, Cina) dengan suhu 75$80^{\circ} \mathrm{C}$ selama 10 menit. Selama 3 menit pertama proses ekstraksi, larutan diaduk dengan kecepatan 4, kemudian tidak diaduk pada menit selanjutnya. Campuran fosfat terdiri dari SAPP dan asam fosfat dengan konsentrasi SAPP yang digunakan yaitu S1 $(650 \mathrm{mg} / \mathrm{L})$ dan $\mathrm{S} 2$ (1300 mg/L). Konsentrasi asam fosfat yang digunakan yaitu A1 (125 mg/L), A2 (250 $\mathrm{mg} / \mathrm{L})$, dan A3 (500 mg/L). Campuran SAPP dan asam fosfat tersebut menghasilkan 6 perlakuan fosfat yaitu A1S1, A2S1, A3S1, A1S2, A2S2, dan A3S2. Ekstrak teh disaring dengan ayakan stainless steel ukuran 80 mesh (Tokyo Screen Co. Ltd, Jepang) untuk memisahkan antara ampas daun dengan ekstrak teh. Ekstrak teh kemudian disaring lagi dengan vacuum pump (Winlab WLH-85DL, Jerman) dan kertas saring No.2 (Advantec, Jepang) untuk mendapatkan ekstrak teh yang lebih jernih.

\section{Pre- formulasi RTD (Xu et al., 2010)}

Ekstrak teh hijau yang sudah diekstraksi dengan dan tanpa fosfat ditambah dengan gula dan asam askorbat saat tahap pencampuran. Sampel yang tersusun atas komposisi tersebut disebut preRTD. Pre-RTD dibuat untuk mengamati parameter esktrak teh setelah ditambah gula dan asam askorbat dan sebelum ditambahkan natrium bikarbonat. Jumlah gula dan asam askorbat yang ditambahkan pada semua sampel adalah sama, yaitu masingmasing $60 \mathrm{~g} / \mathrm{L}$ dan $200 \mathrm{mg} / \mathrm{L}$. 


\section{Formulasi RTD (Xu et al., 2010)}

Minuman RTD teh hijau tersusun atas ekstrak teh yang diekstraksi dengan dan tanpa fosfat, asam askorbat, gula, dan natrium bikarbonat. Jumlah gula dan asam askorbat yang ditambahkan sama seperti pre-RTD, sedangkan jumlah natrium bikarbonat yang ditambahkan pada setiap sampel berbedabeda, namun semua sampel memiliki pH RTD yang sama, yaitu $6,1 \pm 0,2$. Penambahan Na-bikarbonat pada RTD bertujuan untuk meningkatkan $\mathrm{pH}$ sehingga mendekati netral. Nilai $\mathrm{pH}$ sampel RTD dibuat pada kisaran tersebut disebabkan konsep RTD teh hijau dalam penelitian ini adalah teh hijau original, bukan RTD teh hijau rasa buah yang memiliki $\mathrm{pH}<4,0$.

\section{Preparasi sampel}

Sampel ekstrak teh, pre-RTD, dan RTD masing-masing ditambah dengan air RO hingga volumenya $1 \mathrm{~L}$. Sampel ekstrak teh tersebut diperoleh dari seluruh hasil ekstraksi $5 \mathrm{~g}$ daun teh hijau dalam $150 \mathrm{~g}$ air RO. Sampel dipanaskan hingga suhu nya $90-95^{\circ} \mathrm{C}$, kemudian diisikan pada botol hot filling (isi-panas) PET $350 \mathrm{~mL}$. Setelah proses hot filling (isi-panas) ke dalam kemasan, produk ditutup, dibalik posisinya, didiamkan selama 2-3 menit, kemudian didinginkan (Hariyadi, 2013).

Keberadaan oksigen pada head space (ruang kosong) produk dan transmisi oksigen selama penyimpanan disimulasikan dengan memindahkan sampel yang telah diproses hot filling (isi-panas) ke botol aseptik PET dengan volume yang lebih sedikit dari kapasitas brimful (penuh) botol. Botol aseptik PET yang digunakan memiliki kapasitas brimful $375,5 \mathrm{~mL}$ dan oxygen transmission rate (OTR) sebesar 0,066447 cc/hari/kemasan. Volume sampel pada penyimpanan suhu ruang pada botol aseptik PET adalah $330 \mathrm{~mL}$, sehingga head space pada kondisi normal adalah 45,5 mL. Pada penelitian ini, sampel disimulasikan mengalami transmisi oksigen seperti penyimpanan selama 60 hari pada suhu ruang, sehingga jumlah transmisi oksigennya yaitu 3,99 cc. Persentase oksigen di dalam udara yaitu $21 \%$, sehingga total udara yang masuk pada kondisi tersebut yaitu 18,98 cc. Total transmisi udara pada kondisi inkubasi adalah 64,48 cc. Berdasarkan perbandingan volume sampel dengan volume udara pada kondisi normal dan inkubasi, maka diperoleh volume sampel yang dipindahkan ke botol aseptik PET yaitu $314 \mathrm{~mL}$. Sampel tersebut kemudian diinkubasi pada inkubator (Winlab INC 300D, Jerman) pada suhu $60^{\circ} \mathrm{C}$ selama 2 hari. Suhu inkubasi tersebut mengacu pada Nagai dan Sato (2001).

\section{Analisis pH dan warna}

Alat $\mathrm{pH}$ meter (Horiba F-71 A, Jepang) digunakan untuk mengukur nilai $\mathrm{pH}$ sampel pada suhu $28^{\circ} \mathrm{C}$. Analisis warna dilakukan dengan mengukur absorbans sampel dengan spektrofotometer UV-Vis (Hitachi U2900, Jepang) pada panjang gelombang $420 \mathrm{~nm}$. Berdasarkan Liu et al. (2019), panjang gelombang $420 \mathrm{~nm}$ dapat digunakan sebagai indikator pencokelatan. Selain itu, dilakukan pengukuran nilai $L^{*}$, $a^{*}$, dan $b^{*}$ dengan colorimeter (Hunterlab Colorflex EZ, USA). Berdasarkan sistem pewarnaan CIE L*a*b*, nilai $L^{*}$ yang semakin tinggi menunjukkan sampel semakin cerah, sedangkan semakin rendah menunjukkan sampel semakin gelap. Data $\mathrm{L}^{*} \mathrm{a}^{*} \mathrm{~b}^{*}$ dari pengukuran colorimeter kemudian diolah untuk mendapatkan nilai ${ }^{\circ} \mathrm{Hue}\left(\mathrm{H}^{*}\right)$ dan Chroma $\left(C^{*}\right)$. Nilai $H^{*}$ diperoleh dengan arctan $\left[b^{*} / a^{*}\right]$, sedangkan nilai $C^{\star}$ diperoleh dengan $\left(a^{*^{2}}+b^{*^{2}}\right)^{1 / 2}$. Nilai $C^{*}$ menggambarkan tingkat saturasi/kepekatan warna, sedangkan nilai $\mathrm{H}^{*}$ menggambarkan jumlah relatif merah dan kuning. Semakin rendah nilai $\mathrm{H}^{*}$ maka sampel semakin merah (Kortei et al., 2015).

\section{Analisis tanin (Iwasa, 1975)}

Sampel teh direaksikan dengan reagen ferrous tartrate dan bufer fosfat $\mathrm{pH} 7,5$. Reagen ferrous tartrate terdiri dari campuran ferrous sulphate heptahydrate (Merck, Jerman) dan sodium potassium tartrate tetrahydrate (Merck, Jerman). Bufer fosfat terdiri dari campuran disodium hydrogen phosphate (Merck, Jerman) dan potassium dihydrogen phosphate (Merck, Jerman). Pengukuran tanin dilakukan dengan memipet sampel teh atau etil galat (Merck, Jerman) sebanyak $1 \mathrm{~mL}$ ke dalam labu volumetrik $25 \mathrm{~mL}$. Sampel kemudian direaksikan dengan $5 \mathrm{~mL}$ reagen ferrous tartrate dan ditambahkan dengan bufer fosfat $\mathrm{pH} 7,5$ hingga volumenya $25 \mathrm{~mL}$. Sampel lalu diukur nilai absorbansnya pada panjang gelombang $540 \mathrm{~nm}$ menggunakan spektrofotometer UV-VIS (Hitachi U2900, Jepang) setelah 2 menit reaksi. Konsentrasi tanin sampel dihitung berdasarkan kurva standar etil galat. Absorbans $1 \mathrm{mg}$ etil galat setara dengan $1,5 \mathrm{mg}$ tanin.

\section{Analisis data (McHugh, 2011)}

Penelitian ini dilakukan dengan dua kali ulangan. Analisis data dilakukan pada sampel ekstrak teh, pre-RTD, dan RTD sebelum hot filling, setelah hot filling (sebelum inkubasi), dan setelah inkubasi. Analisis data sebelum hot filling bertujuan mengamati parameter pada sampel sebelum terpapar oleh panas. Data yang diperoleh kemudian diuji korelasi Pearson antara jumlah fosfor yang digunakan dengan parameter yang diamati setelah inkubasi. Selain itu, untuk melihat siginifikansi parameter yang diamati pada setiap perlakuan, data dianalisis dengan one way analysis of variance (analisis ragam satu arah)/ANOVA software IBM SPSS versi 16.0. Jika terdapat perbedaan yang nyata pada taraf kepercayaan $95 \%$, maka dilakukan uji lanjut Tukey untuk membandingkan signifikansi pada setiap konsentrasi campuran fosfat. Ketiga 
jenis sampel (ekstrak teh, pre-RTD, dan RTD) merupakan kelompok yang berbeda dan dianalisis statistik pada masing-masing kelompok.

\section{HASIL DAN PEMBAHASAN}

\section{Pengaruh jumlah fosfor terhadap pH ekstrak teh, pre-RTD, dan RTD}

Nilai $\mathrm{pH}$ dan jumlah fosfor yang digunakan dalam larutan pengekstrak dapat dilihat pada Tabel 1. Tabel tersebut menunjukkan bahwa $\mathrm{pH}$ larutan pengekstrak yang mengandung campuran fosfat berkisar 2,6-3,0. Terdapat tiga kelompok sampel yang berbeda signifikan berdasarkan nilai $\mathrm{pH}$. Sampel dengan jumlah asam fosfat yang berbeda tetapi jumlah SAPP yang sama memiliki $\mathrm{pH}$ yang berbeda signifikan. Berdasarkan total fosfor, terdapat dua kelompok sampel yang berbeda signifikan. Sampel dengan jumlah asam fosfat yang sama dengan SAPP berbeda memiliki pH yang tidak berbeda signifikan, tetapi memiliki total fosfor yang berbeda signifikan. Hal tersebut menunjukkan bahwa penambahan asam fosfat dalam penelitian ini berpengaruh signifikan terhadap penurunan $\mathrm{pH}$, sementara SAPP berpengaruh signifikan terhadap penambahan total fosfor pada air pengekstrak.

Tabel 1. Komposisi larutan pengekstrak

\begin{tabular}{|c|c|c|c|c|}
\hline \multirow[b]{2}{*}{ Sampel } & \multicolumn{2}{|c|}{ Dosis (mg/L) } & \multirow{2}{*}{$\begin{array}{l}\text { pH Larutan } \\
\text { Pengekstrak }\end{array}$} & \multirow{2}{*}{$\begin{array}{l}\text { Total } \\
\text { Fosfor } \\
\text { (mg/L) }\end{array}$} \\
\hline & SAPP & $\begin{array}{l}\text { Asam } \\
\text { Fosfat }\end{array}$ & & \\
\hline Kontrol & - & - & $6,5-8,5$ & - \\
\hline $\mathrm{A} 1$ & - & 125 & $3,0 \pm 0,1$ & 39,5 \\
\hline $\mathrm{A} 2$ & - & 250 & $2,8 \pm 0,0$ & 79,0 \\
\hline A3 & - & 500 & $2,6 \pm 0,1$ & 158,0 \\
\hline S1 & 650 & - & $4,8 \pm 0,1$ & 181,5 \\
\hline S2 & 1300 & - & $4,7 \pm 0,4$ & 363,0 \\
\hline A1S1 & 650 & 125 & $3,0 \pm 0,0^{a}$ & $221,0^{\mathrm{b}}$ \\
\hline A2S1 & 650 & 250 & $2,9 \pm 0,0^{b}$ & $260,5^{\mathrm{b}}$ \\
\hline A3S1 & 650 & 500 & $2,6 \pm 0,0^{c}$ & $339,5^{\mathrm{b}}$ \\
\hline A1S2 & 1300 & 125 & $3,2 \pm 0,0^{a}$ & $402,5^{a}$ \\
\hline A2S2 & 1300 & 250 & $2,9 \pm 0,0^{b}$ & $442,0^{a}$ \\
\hline A3S2 & 1300 & 500 & $2,7 \pm 0,0^{c}$ & $521,0^{a}$ \\
\hline
\end{tabular}

Keterangan: Huruf yang sama pada kolom yang sama berarti tidak berbeda nyata pada $\alpha=0,05$

Asam fosfat digunakan dalam penelitian Choung dan Lee (2011) untuk membuat kondisi ekstraksi teh hijau menjadi asam, sehingga reaksi penyebab ketidakstabilan katekin dapat dihambat. Berdasarkan penelitian Zeng et al. (2016), kondisi $\mathrm{pH}$ asam dapat membuat katekin stabil, dan reaksi epimerisasi, degradasi, maupun polimerisasi dapat menurun. Penelitian tersebut juga menunjukkan bahwa katekin stabil dalam $\mathrm{pH} 3,0$ dan suhu $100^{\circ} \mathrm{C}$. Berdasarkan Zimmermann dan Gleichenhagen
(2011), pH memiliki peranan penting dalam efisiensi ekstraksi karena perubahan struktur flavanol diperlambat dengan menurunnya $\mathrm{pH}$. Penelitian Spiro dan Price (1987) menunjukkan bahwa $\mathrm{pH}$ yang semakin asam dapat meningkatkan konsentrasi theaflavin yang terekstrak pada teh hitam. Hal tersebut dapat disebabkan ion hidrogen dapat memecah struktur daun dan/atau memecah ikatan pada theaflavin yang terperangkap, sehingga dapat membuka struktur daun yang biasanya tidak dapat diakses.

Gambar 1 menunjukkan $\mathrm{pH}$ ekstrak teh, preRTD, dan RTD setelah inkubasi. Nilai pH merupakan skala yang menunjukkan konsentrasi ion hidrogen dalam suatu larutan. Ion hidrogen yang dimiliki oleh asam fosfat dan SAPP berkontribusi terhadap penurunan nilai $\mathrm{pH}$ larutan pengekstrak. Hasil uji ANOVA menunjukkan bahwa ekstrak teh yang diesktraksi dengan fosfat memiliki $\mathrm{pH}$ yang lebih rendah dan berbeda signifikan dengan ekstrak teh tanpa fosfat, baik setelah ekstraksi, setelah proses hot filling, dan setelah inkubasi. Setelah ekstraksi, penambahan fosfor $521 \mathrm{mg} / \mathrm{L}$ mampu menurunkan $\mathrm{pH}$ ekstrak dari $5,83 \pm 0,18$ menjadi $2,93 \pm 0,04$. Berdasarkan uji korelasi Pearson, terdapat korelasi signifikan yang negatif antara jumlah fosfor dengan $\mathrm{pH}$ ekstrak teh setelah inkubasi $(r=-0,768)$. Penelitian Vuong et al. (2013) menunjukkan bahwa $\mathrm{pH}$ ekstraksi sangat berpengaruh terhadap stabilitas katekin. Katekin yang diekstrak pada kondisi asam meningkatkan stabilitas EGCG, EGC, dan ECG.

Pada pre-RTD, terlihat bahwa terdapat perbedaan $\mathrm{pH}$ yang signifikan antara sampel kontrol dengan perlakuan fosfat hingga setelah sampel diinkubasi. Penambahan asam askorbat pada sampel kontrol mampu menurunkan $\mathrm{pH}$ ekstrak teh hingga $\mathrm{pH} 4,0$. Adanya penambahan asam askorbat pada semua sampel, baik sampel kontrol maupun perlakuan fosfat, membuat pH pre-RTD sebelum proses hot filling berada pada kisaran 2,8-4,0. Semakin tinggi jumlah fosfor yang ditambahkan, maka $\mathrm{pH}$ pre-RTD semakin rendah. Hal tersebut ditunjukkan dengan adanya korelasi signifikan yang negatif antara jumlah fosfor dengan $\mathrm{pH}$ pre-RTD setelah inkubasi $(r=-0,722)$. Berdasarkan $\mathrm{Li}$ et al. (2012), $\mathrm{pH}$ 4,0 merupakan $\mathrm{pH}$ optimum untuk menjaga stabilitas katekin konfigurasi cis (EGCG, EGC, ECG, dan EC). Semakin tinggi $\mathrm{pH}$, katekin semakin terdegradasi, namun $\mathrm{pH}$ yang terlalu rendah juga dapat meningkatkan degradasi katekin. Saat diformulasikan sebagai RTD, terdapat penambahan natrium bikarbonat pada semua sampel, sehingga $\mathrm{pH}$ sampel berada pada kisaran $6,1 \pm 0,2$. Hal tersebut menyebabkan pH RTD pada semua perlakuan tidak berbeda signifikan hingga setelah RTD diinkubasi. 


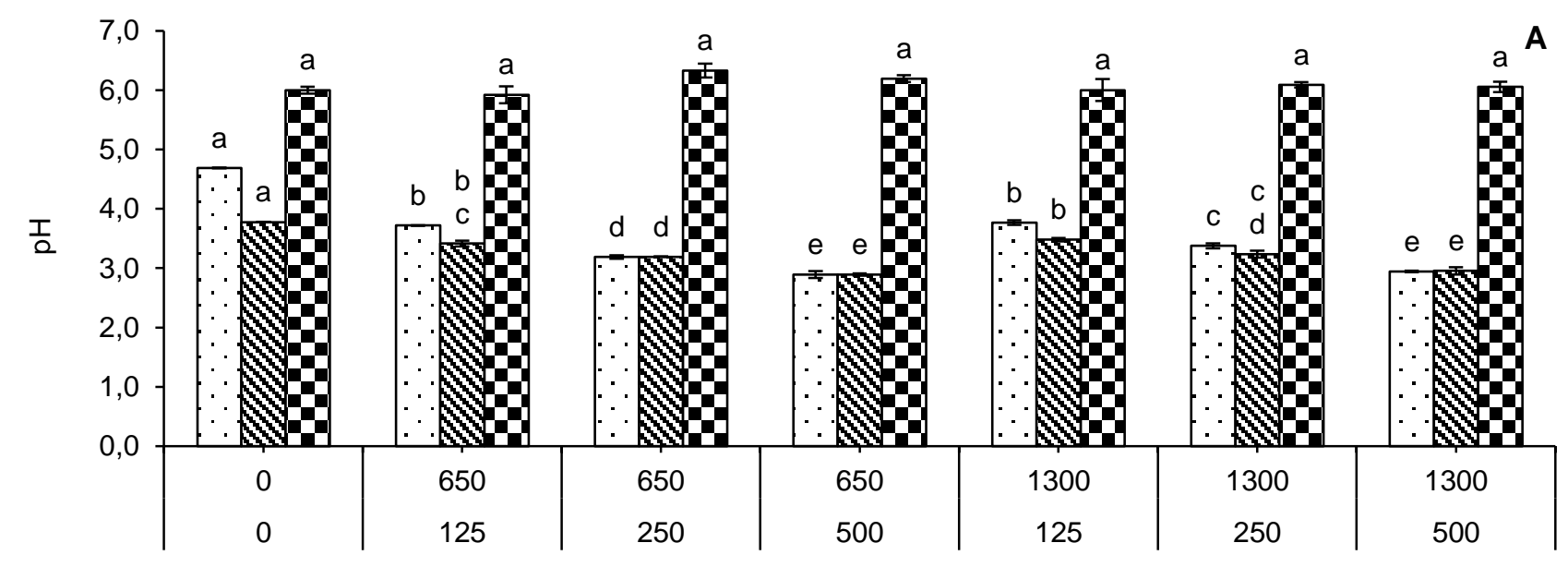

Konsentrasi SAPP dan Asam Fosfat (mg/L)

๑Ekstrak Teh $\quad$ Pre-RTD $\mathbf{D R T D}$
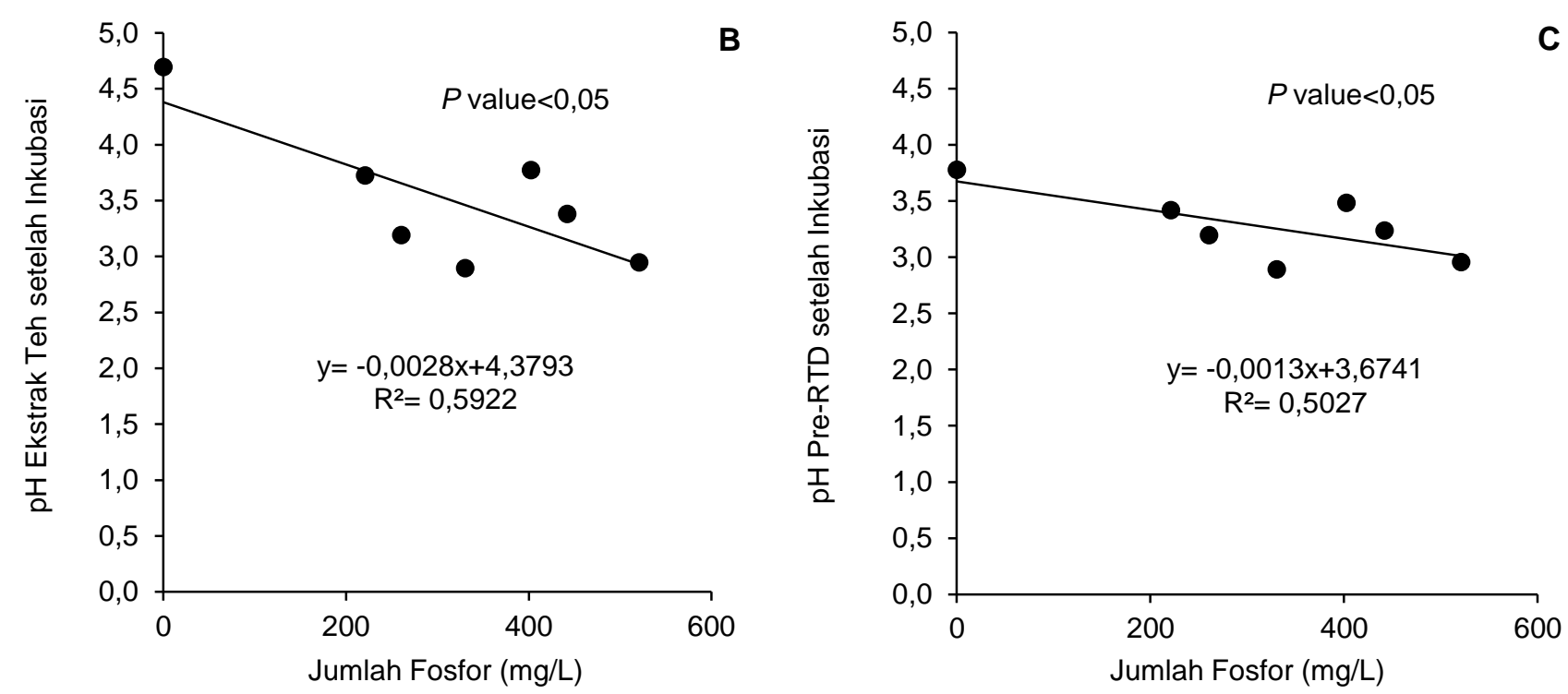

Gambar 1. pH ekstrak teh, pre-RTD, dan RTD setelah inkubasi dengan penambahan berbagai konsentrasi SAPP dan asam fosfat (A). Korelasi jumlah fosfor dengan $\mathrm{pH}$ setelah inkubasi pada ekstrak teh (B) dan pre-RTD (C)

Natrium bikarbonat dapat termasuk dalam bahan tambahan pengatur keasaman (BPOM, 2019). Saat dilarutkan dalam air, natrium bikarbonat membentuk ion natrium $\left(\mathrm{Na}^{+}\right)$, ion hidroksil $\left(\mathrm{OH}^{-}\right)$, dan asam karbonat $\left(\mathrm{H}_{2} \mathrm{CO}_{3}\right)$. Penambahan natrium bikarbonat dapat meningkatkan $\mathrm{pH}$ karena meningkatnya konsentrasi $\mathrm{OH}^{-}$dalam larutan. Selain itu, kondisi larutan dapat menjadi alkali karena bertambahnya konsentrasi ion bikarbonat $\left(\mathrm{HCO}_{3}^{-}\right)$.

\section{Pengaruh jumlah fosfor terhadap warna (A420) ekstrak teh, pre-RTD, dan RTD}

Hasil analisis warna (A420) ekstrak teh, preRTD, dan RTD setelah inkubasi dapat dilihat pada
Gambar 2. Pada hasil tersebut, terlihat bahwa ekstraksi dengan campuran fosfat menghasilkan absorbans pada $420 \mathrm{~nm}$ yang lebih rendah signifikan dibandingkan ekstraksi tanpa fosfat setelah inkubasi. Setelah inkubasi, teh yang diekstrak dengan jumlah campuran fosfat tertinggi memiliki A420 $0,113 \pm 0,020$, sedangkan teh yang diekstraksi tanpa fosfat memiliki A420 0,309 $\pm 0,005$. Nilai A420 yang semakin rendah menunjukkan intensitas pencokelatan yang semakin rendah. Uji korelasi Pearson menunjukkan intensitas pencokelatan ekstrak teh setelah inkubasi berkorelasi signifikan negatif dengan jumlah fosfor yang ditambahkan $(r=-0,768)$. Selain sebagai penurun $\mathrm{pH}$, fosfat dapat berperan sebagai 
pengikat ion-ion logam yang terdapat dalam minuman teh. Ion-ion logam (misalnya Fe), dapat membentuk kompleks dengan katekin, kemudian mengkatalis reaksi autooksidasi dari katekin, sehingga menurunkan aktivitas antioksidannya (Ananingsih et al., 2013). Kombinasi antara ferric pirofosfat dan $\mathrm{pH}$ rendah dapat dilakukan untuk meminimalisasi perubahan warna akibat terbentuknya kompleks katekin dengan besi (Bijlsma et al., 2020).

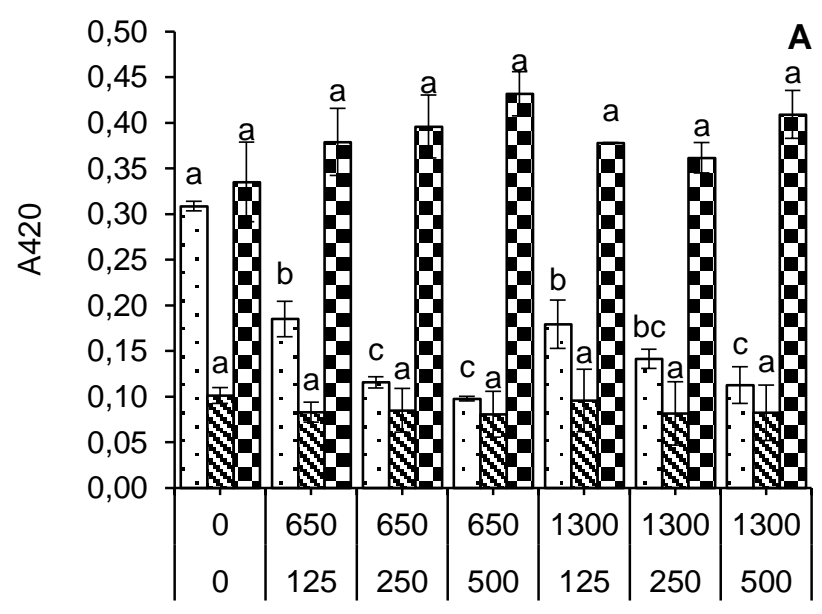

Konsentrasi SAPP dan Asam Fosfat (mg/L)

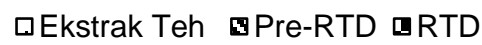

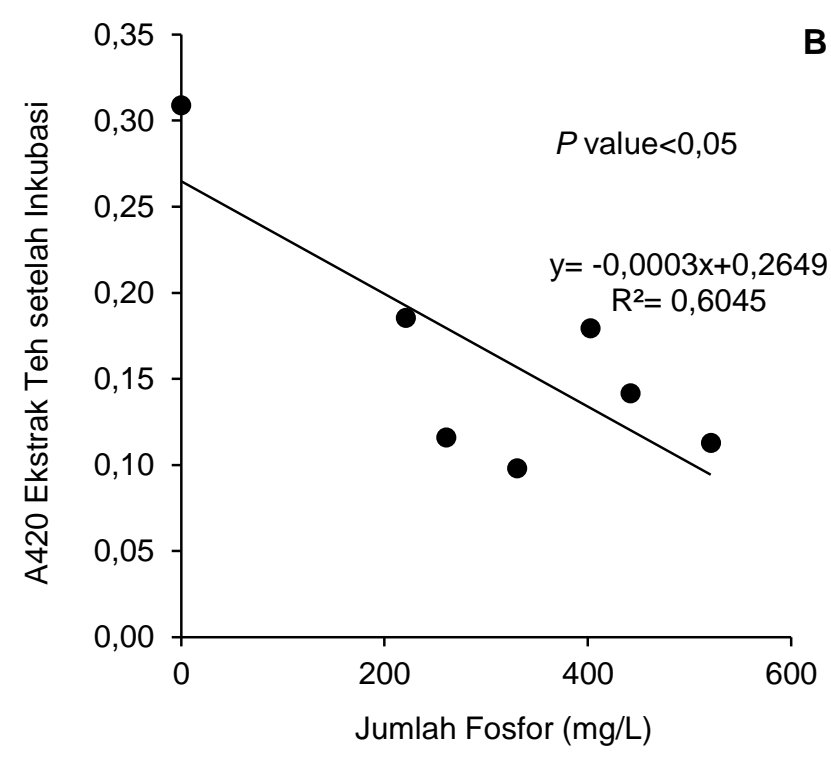

Gambar 2. Absorbans pada $420 \mathrm{~nm}$ ekstrak teh, pre-RTD, dan RTD setelah inkubasi dengan penambahan berbagai konsentrasi SAPP dan asam fosfat (A). Korelasi jumlah fosfor dengan absorbans pada $420 \mathrm{~nm}$ setelah inkubasi pada ekstrak teh (B)
Kualifikasi air reverse osmosis (RO) yang digunakan dalam proses ekstraksi maupun pencampuran pada penelitian ini dapat dilihat pada Tabel 2. Air RO merupakan air yang telah mengalami pemisahan padatan terlarut dan senyawa organik. Teknologi RO merupakan teknologi pemisahan pada air melalui membran dengan menggunakan tekanan di atas tekanan osmotik air, sehingga dapat memisahkan garam, koloid, mikroorganisme, serta senyawa organik yang memiliki berat molekul lebih besar dari 150 (Jiang et al., 2018).

Penelitian Zhang et al. (2017) menunjukkan bahwa jenis air yang digunakan untuk mengekstraksi teh putih memengaruhi jenis senyawa yang terekstrak dan karakteristik sensori ekstrak teh. Ekstraksi dengan air murni $(\mathrm{pH}=6,6)$ menghasilkan skor sensori warna yang paling tinggi dibandingkan dengan menggunakan mata air $(\mathrm{pH}=7,3)$ dan air keran $(\mathrm{pH}=7,4)$. Hal tersebut disebabkan air murni memiliki $\mathrm{pH}$ yang lebih rendah dan ion terlarut yang lebih sedikit dibandingkan mata air dan air keran, sehingga memiliki efek positif terhadap stabilitas pigmen yang larut air (flavonol, antosianin, flavonon, dan flavanol). Selain warna, ekstraksi dengan air murni juga menghasilkan skor sensori tertinggi untuk aroma dan rasa.

Tabel 2. Kualifikasi air RO

\begin{tabular}{lcc}
\hline \multicolumn{1}{c}{ Parameter } & Satuan & Hasil Analisis \\
\hline Warna & - & Normal (jernih) \\
Aroma & - & $\begin{array}{c}\text { Normal (tidak } \\
\text { beraroma) }\end{array}$ \\
Rasa & & Normal (tidak berasa) \\
Konduktivitas & $\mu \mathrm{s} / \mathrm{cm}$ & 2,88 \\
Total padatan & $\mathrm{mg} / \mathrm{L}$ & 1,49 \\
terlarut (TDS) & & \\
Kesadahan & $\mathrm{mg} / \mathrm{L}$ & $<1,0$ \\
pH & - & 6,9 \\
$\mathrm{Fe}$ & $\mathrm{mg} / \mathrm{L}$ & 0,179 \\
\hline
\end{tabular}

Hasil analisis menunjukkan terdapat perbedaan $\mathrm{pH}$ yang signifikan antara kontrol dengan perlakuan fosfat pada pre-RTD, namun warna semua pre-RTD yang dihasilkan tidak berbeda signifikan hingga setelah inkubasi. Hal tersebut dapat disebabkan semua sampel sudah berada pada kondisi asam $(\mathrm{pH}<4,0)$, sehingga katekin stabil dan reaksi oksidasi lebih lambat. Setelah inkubasi, nilai A420 pre-RTD untuk perlakuan fosfat tertinggi adalah $0,083 \pm 0,030$, sedangkan pre-RTD tanpa fosfat memiliki A420 0,101 $\pm 0,009$. Berdasarkan Ellinger (2018), penambahan asam polifosfat sebanyak 0,1$0,2 \%$ dapat menstabilkan asam askorbat. Hal tersebut dapat terjadi disebabkan fosfat dapat berikatan dengan logam penyebab oksidasi asam askorbat. Adanya logam dapat membuat askorbat memiliki efek pro-oksidan, yaitu logam dengan redoks yang aktif direduksi oleh askorbat kemudian bereaksi 
dengan oksigen, sehingga menghasilkan superoksida yang kemudian menghasilkan peroksida $\left(\mathrm{H}_{2} \mathrm{O}_{2}\right)$ (Du et al., 2012).

Fosfat yang ditambahkan saat ekstraksi dapat menurunkan intensitas warna cokelat pada RTD sebelum dan setelah proses hot filling (sebelum inkubasi). Sampel RTD setelah proses hot filling yang mengandung campuran fosfat tertinggi memiliki nilai A420 0,143 $\pm 0,006$, sedangkan RTD kontrol memiliki nilai A420 0,340 $\pm 0,037$. Setelah inkubasi, warna (A420) semua sampel RTD tidak berbeda signifikan. Hal tersebut menunjukkan bahwa ekstraksi teh dengan fosfat belum bisa mem-

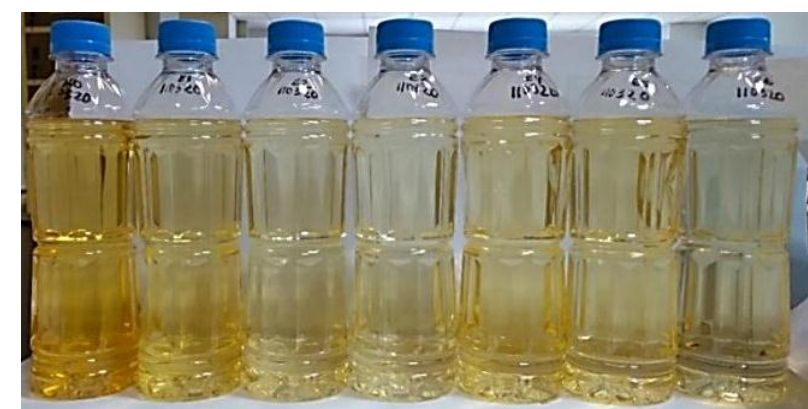

Kontrol A1S1 A2S1 A3S1 A1S2 A2S2 A3S2

$1 \mathrm{~A}$

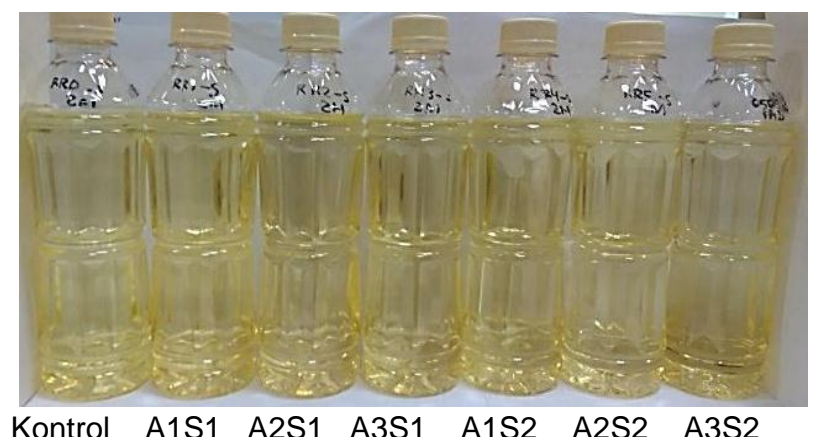

2A

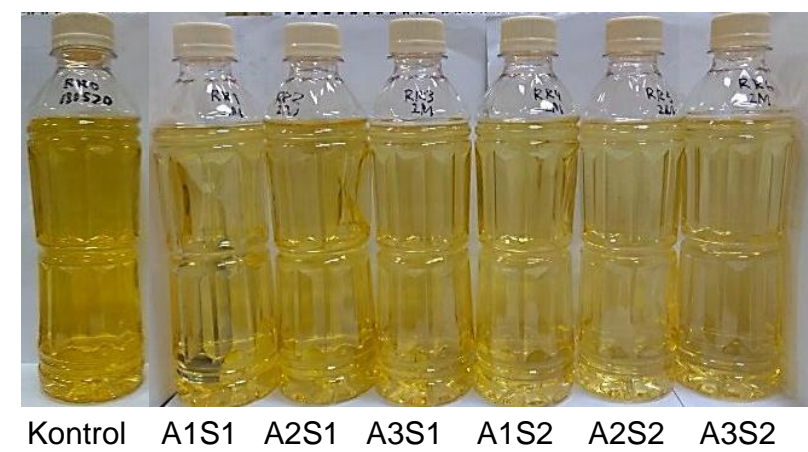

3A perlambat pencokelatan pada teh hijau RTD yang memiliki $\mathrm{pH}$ mendekati netral hingga setelah inkubasi (Gambar 3).

Seluruh sampel baik kontrol maupun perlakuan fosfat mengalami peningkatan A420 setelah inkubasi. Hal tersebut menunjukkan paparan panas dapat meningkatkan intensitas pencokelatan pada sampel ekstrak teh, pre-RTD, dan RTD. Hasil penelitian ini sejalan dengan Zeng et al. (2016) yang menyebutkan bahwa meningkatnya suhu dapat menyebabkan reaksi oksidasi dan degradasi polifenol teh, sehingga warnanya menjadi semakin gelap, semakin kuning, dan kurang hijau.
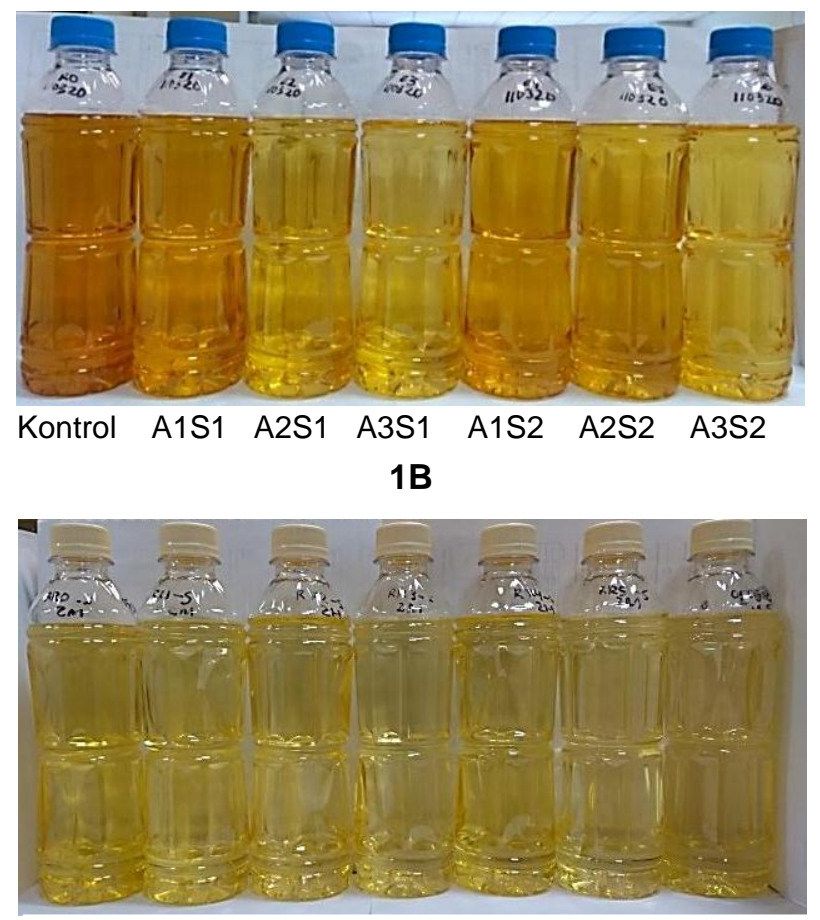

Kontrol A1S1 A2S1 A3S1 A1S2 A2S2 A3S2

2B

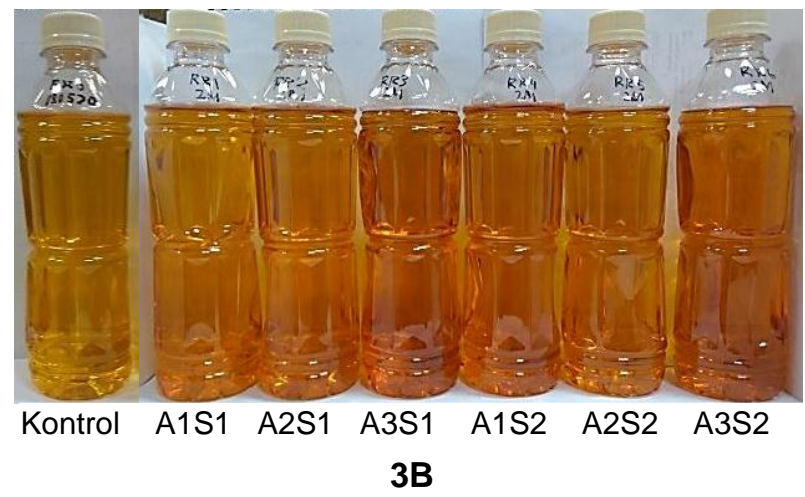

Gambar 3. Penampakan visual ekstrak teh (1) pre-RTD (2) dan RTD (3) sebelum inkubasi (A) dan setelah inkubasi (B) 
Berdasarkan Fan et al. (2015), perubahan warna pada katekin dari tidak berwarna menjadi kuning selama proses pemanasan disebabkan oleh reaksi oksidasi atau kondensasi. Reaksi oligomerisasi non-enzimatis pada epikatekin (EC) dan katekin (C) menghasilkan senyawa dimer yaitu dehidrodikatekin- $A$, yang berwarna kuning pekat dan dapat menyebabkan off-color (warna yang menyimpang) pada minuman teh. Proses terbentuknya senyawa tersebut dapat terjadi akibat proses pemanasan dalam suhu tinggi dan waktu yang lama, meskipun dengan tekanan oksigen yang rendah. Selain reaksi oksidasi, proses panas juga dapat meningkatkan reaksi epimerisasi katekin. EC dan EGC memiliki stabilitas terhadap panas yang lebih rendah dibandingkan dengan jenis katekin yang lainnya. Proses panas utamanya menyebabkan reaksi epimerisasi pada EC, sedangkan reaksi oksidasi pada EGC. Penelitian Vuong et al. (2013) menunjukkan katekin epistruktur tidak stabil pada suhu panas, dan kestabilannya terhadap suhu dipengaruhi oleh $\mathrm{pH}$. Semakin tinggi $\mathrm{pH}$, maka epistruktur katekin semakin banyak terdegradasi dan semakin mudah mengalami epimerisasi.

Teh mengandung asam amino, terutama 50\% nya terdiri dari theanine (Chaturvedula dan Prakash, 2011). Penambahan gula (sukrosa) pada pre-RTD dan RTD dapat memicu reaksi Maillard. Saat sukrosa mengalami pemanasan, maka akan menghasilkan glukosa dan fruktosa. Glukosa merupakan gula pereduksi, dan jika bereaksi dengan gugus amino bebas pada theanine dapat mengalami reaksi Maillard, kemudian menghasilkan warna cokelat. Reaksi Maillard semakin cepat terjadi saat $\mathrm{pH}$ dan suhu semakin tinggi. Hal tersebut ditunjukkan pada penelitian Karseno et al. (2017) pada gula kelapa, yaitu semakin tinggi $\mathrm{pH}$ dan suhu, maka intensitas pencokelatannya semakin tinggi. Pada $\mathrm{pH}$ rendah, grup amino lebih banyak mengalami protonasi, sehingga lebih sedikit grup amino yang tersedia untuk reaksi Maillard. Selain memicu reaksi Maillard, keberadaan sukrosa juga dapat menurunkan stabilitas katekin. Penelitian Lončarić et al. (2017) menyatakan penambahan sukrosa dapat mempercepat reaksi epimerisasi katekin dan epikatekin pada suhu 80 dan $100^{\circ} \mathrm{C}$.

Pengaruh jumlah fosfor terhadap warna $\left(L^{*}, C^{*}\right.$, $H^{\star}$ ) ekstrak teh, pre-RTD, dan RTD

Gambar 4 menunjukkan terdapat perbedaan yang siginifikan antara kontrol dengan perlakuan fosfat pada kecerahan $\left(L^{*}\right)$ ekstrak teh setelah inkubasi. Sampel kontrol memiliki kecerahan yang lebih rendah dibandingkan dengan sampel perlakuan fosfat. Nilai $L^{*}$ antara sampel kontrol dan perlakuan fosfat setelah inkubasi pada sampel yang telah diformulasikan sebagai pre-RTD dan RTD tidak berbeda signifikan. Saat sampel terpapar panas, semua sampel mengalami penurunan nilai $L^{*}$. Jumlah fosfor memiliki korelasi signifikan positif dengan kecerahan ekstrak teh setelah inkubasi $(r=$ 0,778).
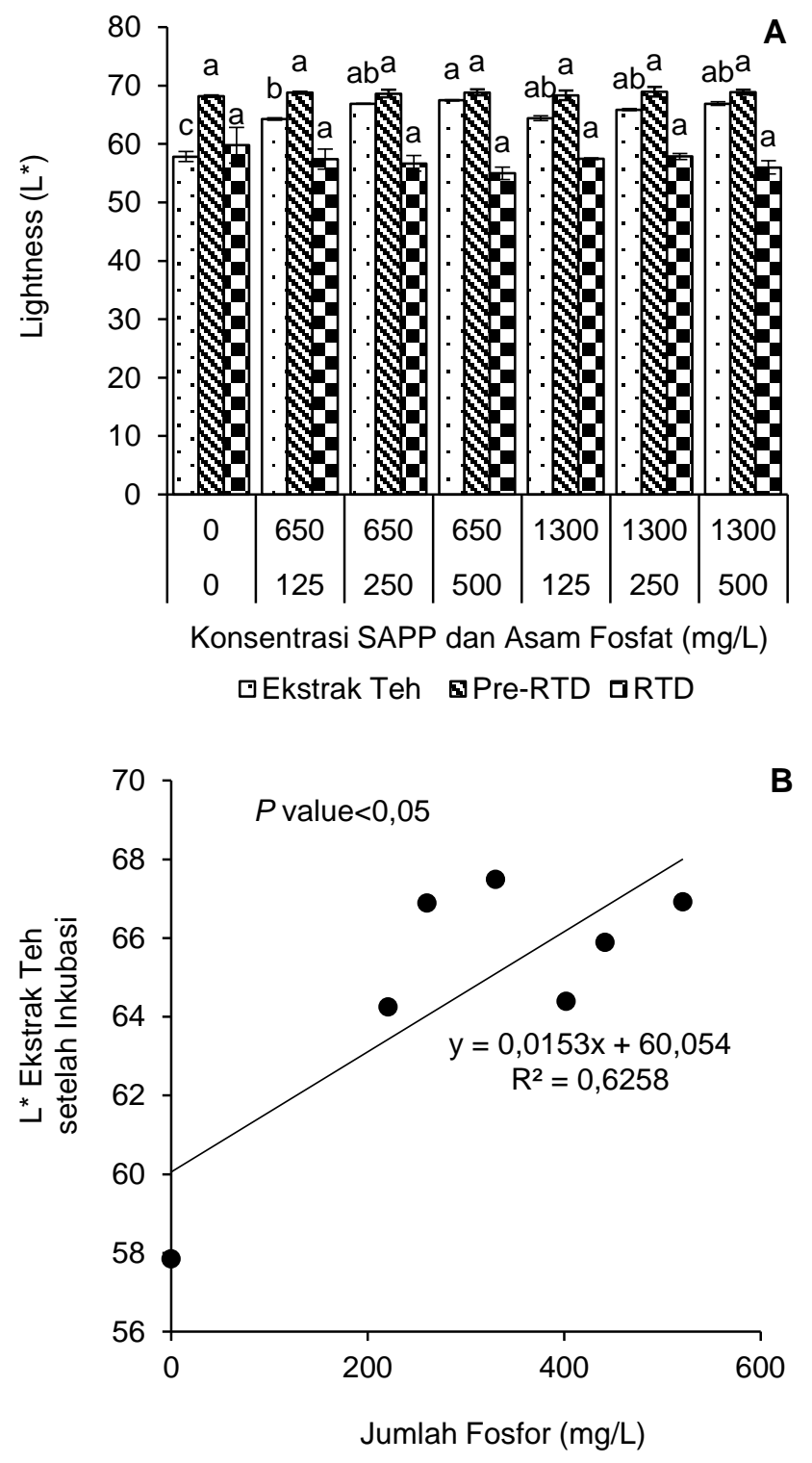

Gambar 4. Kecerahan ekstrak teh, pre-RTD, dan RTD setelah inkubasi dengan penambahan berbagai konsentrasi SAPP dan asam fosfat (A). Korelasi jumlah fosfor dengan kecerahan ekstrak teh setelah inkubasi (B)

Hasil ini sejalan dengan penelitian yang dilakukan oleh Xu et al. (2016), bahwa teh yang diekstraksi dengan air yang memiliki konduktivitas dan $\mathrm{pH}$ yang semakin rendah menghasilkan warna ekstrak yang semakin cerah, semakin hijau, dan kepekatannya semakin menurun (nilai $L^{*}$ dan $\mathrm{H}^{*}$ 
yang semakin tinggi dan $\mathrm{C}^{*}$ semakin rendah). Semakin tinggi $\mathrm{pH}$ air yang digunakan untuk ekstraksi teh $(\mathrm{pH}>6,0)$, maka dapat meningkatkan oksidasi katekin dan membentuk senyawa yang berwarna. Penelitian Orona dan Medina (2019) juga menunjukkan semakin lamanya waktu penyimpanan, nilai $L^{*}$ dan $b^{*}$ mengalami penurunan, sedangkan nilai $a^{*}$ mengalami peningkatan.

Nilai ${ }^{\circ}$ Hue $\left(\mathrm{H}^{*}\right)$ ekstrak teh, Pre-RTD, dan RTD setelah inkubasi dapat dilihat pada Gambar 5. Hasil tersebut menunjukkan bahwa setelah inkubasi, nilai $\mathrm{H}^{*}$ ekstrak teh yang diekstraksi dengan fosfat memiliki nilai $\mathrm{H}^{*}$ lebih tinggi signifikan dibandingkan tanpa fosfat. Nilai $\mathrm{H}^{*}$ ekstrak teh setelah inkubasi memiliki korelasi signifikan yang positif $(r=0,728)$ dengan jumlah fosfor yang ditambahkan. Setelah diformulasikan sebagai pre-RTD dan RTD, teh yang diekstraksi dengan fosfat memiliki nilai $\mathrm{H}^{*}$ yang tidak berbeda signifikan dengan masing-masing kontrol setelah inkubasi. Nilai $\mathrm{H}^{*}$ sampel ekstrak teh, preRTD, dan RTD mengalami penurunan saat terpapar oleh panas. Hal tersebut menunjukkan intensitas warna hijau berkurang dan kuning meningkat.

Nilai chroma $\left(C^{*}\right)$ ekstrak teh, pre-RTD, dan RTD setelah inkubasi dapat dilihat pada Gambar 6 . Teh yang diesktraksi dengan fosfat memiliki nilai chroma yang lebih rendah signifikan dibandingkan dengan ekstrak teh kontrol setelah inkubasi. Berdasarkan uji korelasi Pearson, dapat dilihat bahwa nilai chroma ekstrak teh setelah inkubasi memiliki korelasi signifikan yang negatif dengan jumlah fosfor yang ditambahkan $(r=-0,710)$.
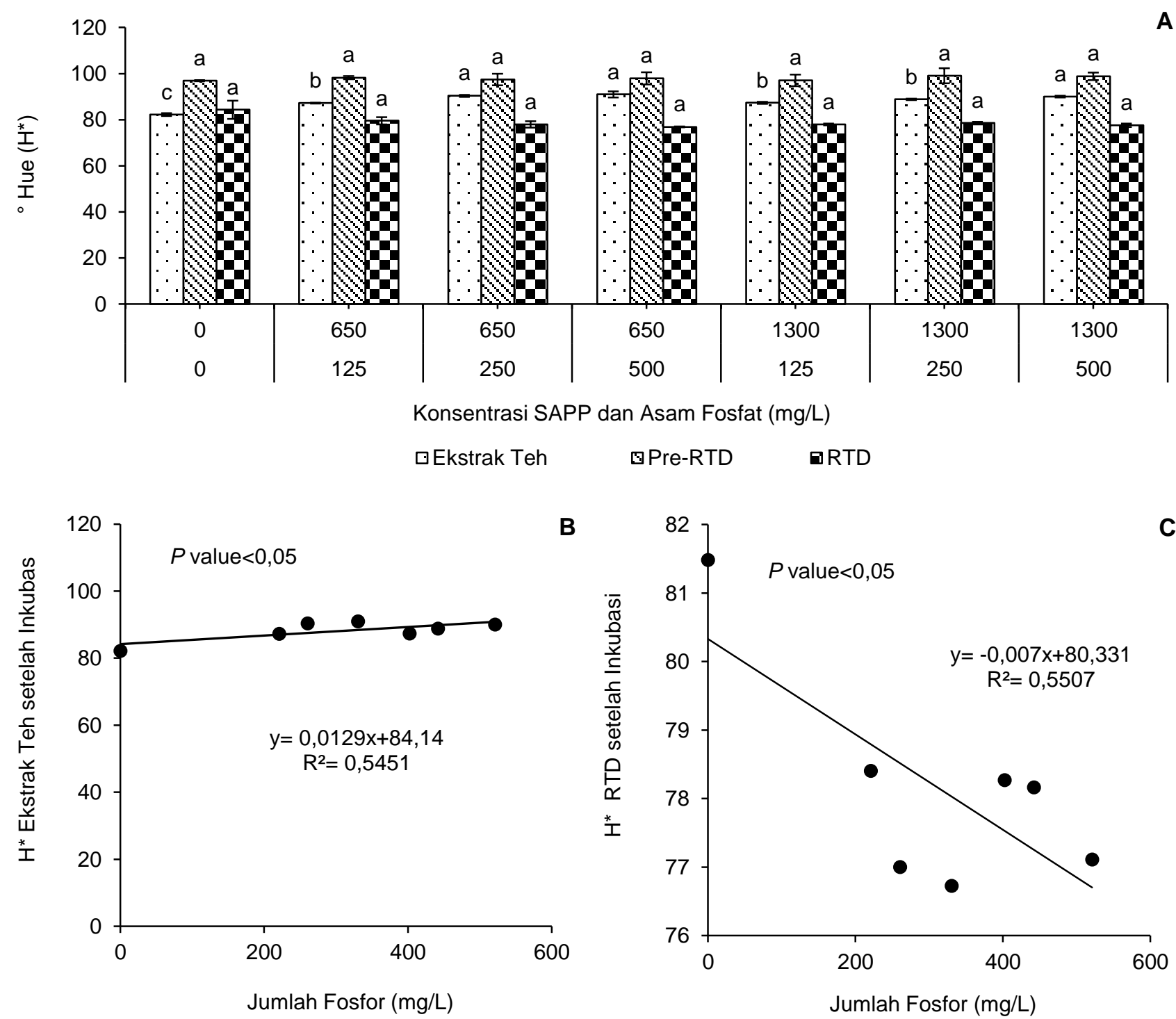

Gambar 5. 'Hue ekstrak teh, pre-RTD, dan RTD setelah inkubasi dengan penambahan berbagai konsentrasi SAPP dan asam fosfat $(A)$. Korelasi jumlah fosfor dengan ${ }^{\circ}$ Hue setelah inkubasi pada ekstrak teh (B) dan RTD (C) 


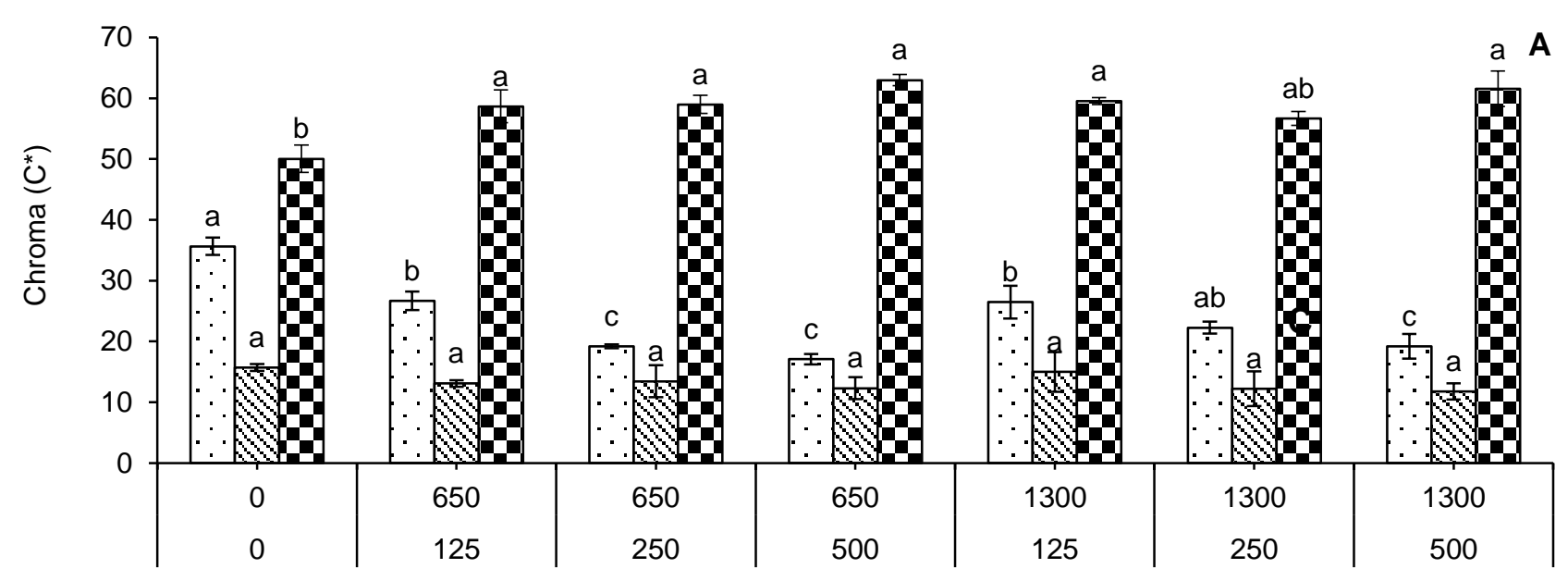

Konsentrasi SAPP dan Asam Fosfat (mg/L)

口Ekstrak Teh $\triangle$ Pre-RTD घRTD
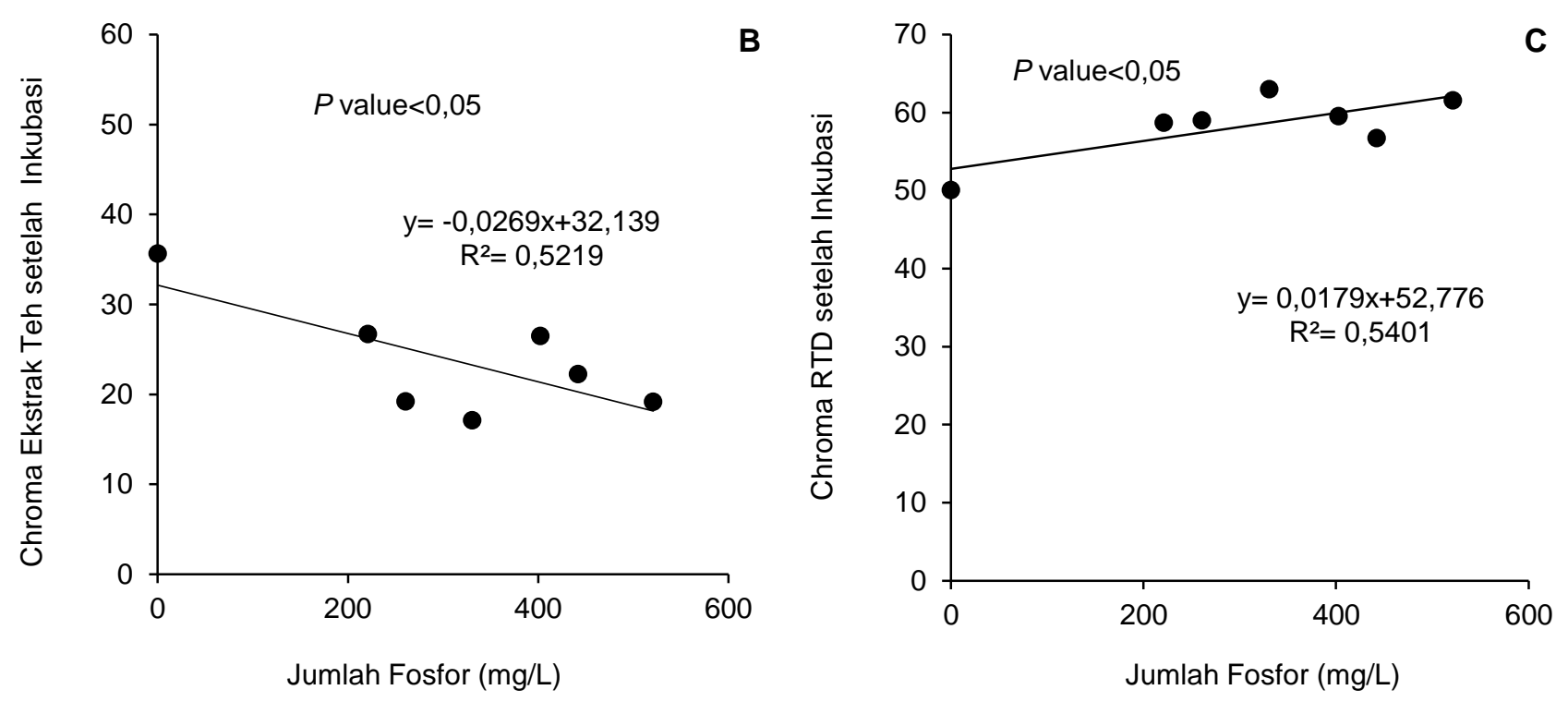

Gambar 6. Chroma ekstrak teh, pre-RTD, dan RTD setelah inkubasi dengan penambahan berbagai konsentrasi SAPP dan asam fosfat (A). Korelasi jumlah fosfor dengan Chroma setelah inkubasi pada ekstrak teh (B) dan RTD (C)

Nilai $C^{*}$ pada semua sampel tidak berbeda signifikan setelah inkubasi saat diformulasikan sebagai pre-RTD, namun setelah diformulasikan pada RTD, nilai $C^{*}$ yang diekstraksi dengan fosfat lebih tinggi signifikan dibandingkan dengan kontrol setelah inkubasi. Hal tersebut menunjukkan intensitas warna teh yang diekstrak dengan fosfat lebih pekat saat diformulasikan sebagai RTD setelah inkubasi. Semakin tinggi nilai chroma, maka warna sampel semakin pekat pada derajat ${ }^{\circ} \mathrm{Hue}$ yang dimiliki. Nilai chroma juga semakin tinggi saat sampel terpapar oleh panas. Berdasarkan hasil uji korelasi Pearson, terdapat korelasi negatif yang signifikan antara jumlah fosfor yang ditambahkan dengan $\mathrm{H}^{*}(r=-$
$0,571)$ dan korelasi positif yang signifikan dengan $C^{*}$ $(r=0,694)$ pada RTD setelah inkubasi.

Penambahan Na-bikarbonat dilakukan pada formulasi RTD hingga pH semua sampel mendekati netral dan berada pada kisaran $6,1 \pm 0,2$. Jumlah $\mathrm{Na}$ bikarbonat yang ditambahkan pada sampel RTD perlakuan fosfat lebih banyak dibandingkan dengan RTD kontrol, karena sampel dengan perlakuan fosfat memiliki $\mathrm{pH}$ lebih rendah. Hal tersebut menyebabkan jumlah ion bikarbonat $\left(\mathrm{HCO}_{3}{ }^{-}\right)$serta ion $\mathrm{OH}^{-}$ yang dihasilkan semakin banyak, sehingga kondisi RTD perlakuan fosfat lebih alkali. Berdasarkan Boyd et al. (2016), total alkalinitas dapat didefinisikan sebagai jumlah anion dalam air yang dapat menetral- 
kan kation hidrogen. Senyawa penyusun alkalinitas dalam air diantaranya hidroksida, karbonat, bikarbonat, amonia, fosfat, borat, silikat, dan asam organik. Keberadaan senyawa tersebut dapat mempertahankan $\mathrm{pH}$ dengan menetralkan asam.

Penelitian yang dilakukan oleh Zeng et al. (2016) disebutkan bahwa kondisi alkali menyebabkan polifenol teh tidak stabil. Terdapat korelasi antara nilai absorbans $420 \mathrm{~nm}$ setelah inkubasi dengan nilai $L^{*}, H^{*}$, dan $C^{*}$ setelah inkubasi. Berdasarkan uji korelasi Pearson, nilai $\mathrm{L}^{*}$ dan $\mathrm{H}^{*}$ pada ekstrak teh setelah inkubasi memiliki korelasi signifikan yang negatif dengan nilai pada A420 $(r=-0,979)$, sementara nilai $C^{*}$ memiliki korelasi signifikan yang positif $(r=0,989)$ dengan nilai A420. Korelasi yang sama juga ditunjukkan pada sampel pre-RTD dan RTD setelah inkubasi. Nilai A420 pre-RTD setelah inkubasi memiliki korelasi signifikan yang negatif dengan $L^{*}(r=-0,959)$ dan $H^{*}(r=-0,942)$, namun korelasi signifikan positif dengan $C^{*}(r=0,904)$. Nilai A420 RTD setelah inkubasi berkorelasi signifikan negatif dengan $L^{*}(r=-0,979)$ dan $H^{*}(r=-0,888)$, dan berkorelasi signifikan positif dengan $C^{*}(r=0,871)$. Hal tersebut menunjukkan bahwa semakin tingginya intensitas pencokelatan, diiringi dengan semakin menurunnya nilai kecerahan dan nilai Hue, serta semakin pekat warna yang dihasilkan.

\section{Pengaruh jumlah fosfor terhadap tanin ekstrak teh, Pre-RTD, dan RTD}

Tanin merupakan kelompok polifenol yang larut air dan berkontribusi terhadap rasa sepat dan dapat mengikat protein. Tanin dikelompokkan menjadi hydrolysable dan condensed tannin. Condensed tannin merupakan oligomer atau polimer yang terdiri dari flavan-3-ols (monomer katekin) yang dihubungkan dengan ikatan antar karbon (Corral et al., 2020). Kandungan total katekin berkisar antara 13,5-31\% dalam daun teh segar. Katekin dan isomernya termasuk dalam sub kelas flavonoid. Struktur katekin terdiri dari dua gugus fenol (cincin A dan B) dan satu gugus hidroksipiran (cincin $C$ ), karena memiliki gugus fenol, katekin dapat berfungsi sebagai antioksidan (Balittri, 2013). Berdasarkan Tsao dan Li (2012), mekanisme antioksidan senyawa fenolik yaitu dengan transfer atom hidrogen atau elektron bebas melalui proton.

Gambar 7 menunjukkan jumlah tanin ekstrak teh, pre-RTD, dan RTD setelah inkubasi. Teh yang diekstraksi dengan kombinasi SAPP $1300 \mathrm{mg} / \mathrm{L}$ dan asam fosfat $500 \mathrm{mg} / \mathrm{L}$ dapat meningkatkan konsentrasi tanin yang terekstrak hingga $29,8 \%$ dibandingkan ekstraksi tanpa fosfat. Nilai tersebut mendekati dengan hasil penelitian yang telah dilakukan oleh Zimmermann dan Gleichenhagen (2011), yaitu ekstraksi teh dengan menggunakan bufer fosfat $\mathrm{pH} 3,0$ dan 4,8 dapat meningkatkan konsentrasi flavanol yang terekstrak hingga $20 \%$. Berdasarkan pene- litian Lin et al. (2012), daun teh yang dipupuk dengan konsentrasi fosfor yang lebih tinggi menghasilkan total polifenol yang lebih tinggi saat diekstraksi. Total polifenol yang meningkat disebabkan oleh meningkatnya konsentrasi flavonoid, bukan oleh konsentrasi katekin yang meningkat. Pada penelitian tersebut total fosfor tidak berpengaruh signifikan terhadap konsentrasi EGCG, EGC, C, GC, GCG, CG, dan total katekin. Penelitian Huang et al. (2013) menunjukkan bahwa semakin meningkatnya ekstraksi polifenol pada teh hijau dapat meningkatkan aktivitas antioksidan.

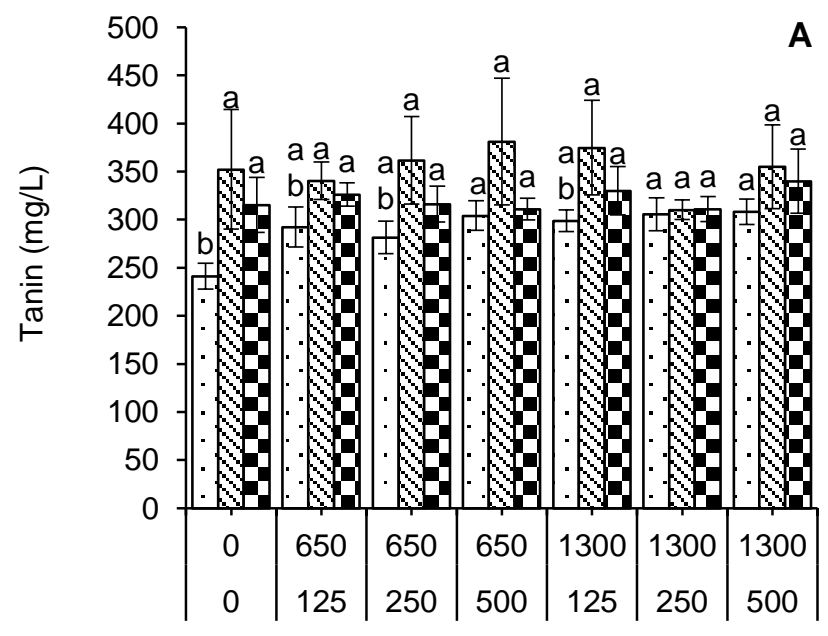

Konsentrasi SAPP dan Asam Fosfat (mg/L)

घEkstrak Teh $\quad$ PPre-RTD $\quad$ RTD

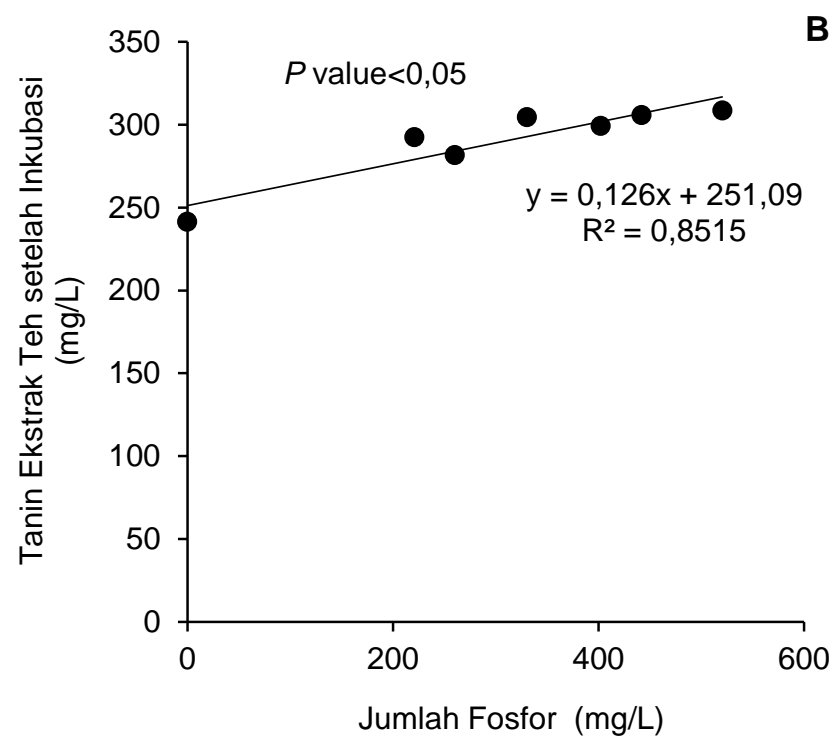

Gambar 7. Tanin ekstrak teh, pre-RTD, dan RTD setelah inkubasi dengan penambahan berbagai konsentrasi SAPP dan asam fosfat (A). Korelasi jumlah fosfor dengan tanin ekstrak teh setelah inkubasi (B) 
Penelitian ini juga ditunjukkan bahwa ekstraksi dengan fosfat dapat meningkatkan konsentrasi tanin setelah inkubasi, sehingga dapat dikatakan bahwa ekstraksi dengan fosfat dapat menstabilkan jumlah tanin. Hasil uji korelasi Pearson menunjukkan terdapat korelasi signifikan yang positif $(r=0,822)$ antara jumlah fosfor dengan kandungan tanin ekstrak teh setelah inkubasi.

Berdasarkan Xu et al. (2016), kapasitas antioksidan ekstrak teh dipengaruhi oleh $\mathrm{pH}$ dan konduktivitas air yang digunakan untuk ekstraksi. Nilai $\mathrm{pH}$ dan konduktivitas air memiliki korelasi signifikan yang negatif dengan kapasitas antioksidan. Kapasitas antioksidan pada ekstrak teh utamanya dipengaruhi oleh katekin. Semakin rendah $\mathrm{pH}$ dan konduktivitas air pengekstrak, maka jumlah ekstrak dan stabilitas katekin semakin meningkat. Pada penelitian ini, jumlah tanin tidak berbeda signifikan antar perlakuan setelah inkubasi pada pre-RTD dan RTD. Pada pre-RTD, semua sampel setelah inkubasi memiliki kisaran nilai tanin antara 310-362 mg/L. Nilai tanin semua sampel RTD setelah inkubasi berkisar 310-340 mg/L.

Tanin pada semua perlakuan mengalami penurunan setelah proses inkubasi. Rata-rata penurunan tanin pada ekstrak teh, pre-RTD, dan RTD perlakuan fosfat masing-masing yaitu 8,$32 ; 0,30$; dan $7,96 \%$. Penurunan tanin pada ekstrak teh, preRTD, dan RTD kontrol masing-masing yaitu 14,25; 2,06; dan $8,89 \%$. Penurunan tanin setelah inkubasi pada suhu panas disebabkan tanin lebih banyak mengalami oksidasi, sehingga komponen tanin terdegradasi. Reaksi oksidasi akan dipercepat dengan $\mathrm{pH}$ larutan yang semakin tinggi. Telah disebutkan dalam pembahasan sebelumnya bahwa proses inkubasi juga dapat meningkatkan nilai $A 420$ dan $C^{*}$, menurunkan $\mathrm{L}^{*}$ dan $\mathrm{H}^{*}$ pada ekstrak teh, pre-RTD, dan RTD. Hasil ini menunjukkan bahwa proses inkubasi dapat meningkatkan oksidasi tanin, sehingga berefek terhadap warna yang dihasilkan semakin cokelat, kecerahan menurun, serta kepekatan warna meningkat. Berdasarkan Zeng et al. (2016), warna kuning berkorelasi dengan oksidasi polifenol teh. Pada penelitian tersebut, semakin tinggi $\mathrm{pH}$ dan paparan suhu, maka warna teh semakin kuning, ditunjukkan dengan nilai absorbans pada $425 \mathrm{~nm}$ yang semakin tinggi. Selain itu, semakin tinggi $\mathrm{pH}$ juga menurunkan nilai $\mathrm{L}^{*}$ dan meningkatkan nilai $a^{*}$ dan $b^{*}$. Dalam $\mathrm{pH}$ netral, EGCG mudah mengalami autooksidasi. Produk utama dari oksidasi tersebut memiliki struktur dimer dan memiliki berat molekul yang lebih tinggi.

Disebutkan dalam Gadkari dan Balaraman (2015), katekin sensitif terhadap oksidasi, cahaya, suhu tinggi, dan kondisi alkali. Hasil penelitian Hunaefi et al. (2018) menunjukkan bahwa pH dan total fenol mengalami penurunan dengan semakin meningkatnya suhu penyimpanan. Hal yang sama ditunjukkan oleh penelitian Orona dan Medina (2019), yang menyebutkan bahwa ekstrak teh yang telah diproses sterilisasi dan disimpan pada suhu ruang selama 9 hari mengalami penurunan total fenol sebanyak $44,67 \%$, penurunan total katekin $33,40 \%$, dan penurunan total non katekin $56,93 \%$.

Penelitian Chen et al. (2001) menunjukkan stabilitas katekin teh hijau selama proses pemanasan dengan autoklaf pada suhu $120^{\circ} \mathrm{C}$ selama 20 menit dipengaruhi oleh $\mathrm{pH}$. Pada $\mathrm{pH} 3,0$ dan 4,0, katekin teh hijau relatif stabil, tetapi mulai terdegradasi pada $\mathrm{pH} 5,0$ dan 6,0 . Lebih dari $80 \%$ katekin teh hijau masih tersisa setelah proses pemanasan tersebut pada $\mathrm{pH} \mathrm{3,0}$ dan 4,0, tetapi saat $\mathrm{pH} 6,0$, katekin teh hijau hanya tersisa $20 \%$. Semakin meningkatnya waktu penyimpanan, jumlah katekin yang tersisa semakin sedikit pada $\mathrm{pH}$ yang semakin tinggi. Proses sterilisasi dengan panas pada minuman teh dalam kaleng atau botol dapat mengkonversi EGCG menjadi GCG. Penelitian tersebut juga menunjukkan bahwa penggunaan asam askorbat dapat melindungi katekin setelah 1 bulan proses sterilisasi, namun setelah itu asam askorbat berperan sebagai prooksidan, yang dapat memicu degradasi katekin. Asam askorbat (AA) sering digunakan sebagai bahan tambahan pada minuman teh hijau dengan tujuan melindungi stabilitas katekin, namun asam askorbat sangat mudah mengalami oksidasi pada medium cair menjadi asam dehidroaskorbat (DHAA). DHAA dapat melindungi stabilitas EGCG dengan menghambat reaksi hidrolisis, namun dapat juga bereaksi membentuk DHAA-EGCG sehingga dapat memicu degradasi katekin (Chen et al., 2020). Kecepatan oksidasi asam askorbat sangat dipengaruhi oleh $\mathrm{pH}$ medium, suhu, oksigen, dan dikatalis oleh keberadaan logam. Kestabilan asam askorbat paling tinggi pada $\mathrm{pH} 3,0$, sedangkan kestabilannya akan semakin menurun saat $\mathrm{pH}$ medium semakin tinggi (Dolińska et al., 2012)

Nilai konstanta disosiasi asam (Ka) dapat digunakan untuk mengukur kekuatan asam dalam suatu larutan. Semakin besar nilai Ka, atau semakin rendah nilai pKa, maka semakin kuat asam tersebut, karena semakin banyak ion $\mathrm{H}+$ yang dilepaskan. Ion $\mathrm{H}+$ dapat menangkap radikal bebas, sehingga jika semakin banyak ion $\mathrm{H}_{+}$yang dilepaskan maka aktivitas antioksidan dapat meningkat. Tingkat keasaman larutan pengekstrak dapat memengaruhi jumlah ion $\mathrm{H}+$ yang dilepaskan (Achyadi et al., 2018). Yeni et al. (2017) menyebutkan semakin banyak ion $\mathrm{H}+$ bebas, maka dapat meregenerasi senyawa antioksidan dengan cara berikatan dengan radikal fenoksil membentuk senyawa antioksidan kembali. Aktivitas antioksidatif pada antioksidan dapat mengalami perubahan tergantung pada nilai $\mathrm{pH}$ medium dan pKa antioksidan. Berdasarkan Muzolf-Panek et al. (2012), adanya gugus galat 
pada epikatekin galat (ECG), galokatekin galat (GCG), dan epigalokatekin galat (EGCG) dapat menurunkan nilai pKa. Hal tersebut disebabkan jumlah gugus hidroksil meningkat dengan adanya gugus galat. Nilai pKa ECG, GCG, dan EGCG masing-masing yaitu 7,72; 7,61; dan 7,64. Katekin mengalami protonasi saat $\mathrm{pH}$ medium lebih rendah dari pKa katekin, sebaliknya saat berada pada $\mathrm{pH}$ yang lebih tinggi dari $\mathrm{pKa}$, katekin mengalami deprotonasi. Pada penelitian ini, ekstraksi teh dengan campuran fosfat dapat menurunkan pH ekstraksi sehingga tanin berada pada dalam keadaan terprotonasi, kemudian menyebabkan donasi proton menjadi sulit. Berdasarkan Lončarić et al. (2017), pada $\mathrm{pH}$ netral atau basa potensi katekin untuk mendonorkan proton meningkat, sehingga lebih mudah untuk mengalami degradasi.

\section{KESIMPULAN}

Penambahan SAPP dan asam fosfat dengan jumlah 221-521 mg/L pada air pengekstrak sebelum ekstraksi teh hijau dapat menurunkan $\mathrm{pH}$ ekstrak teh dari 5,83 $\pm 0,18$ menjadi 2,8-3,8, meningkatkan kecerahan warna, serta meningkatkan konsentrasi tanin yang terekstrak. Gula dan asam askorbat yang ditambahkan pada ekstrak teh dengan atau tanpa penambahan fosfat dapat membuat $\mathrm{pH}$ semua sampel $<4,0$ dan mempertahankan kecerahan preRTD hingga setelah inkubasi. Penambahan campuran fosfat pada teh yang mengandung natrium bikarbonat ( $\mathrm{pH}$ mendekati netral), belum memperlihatkan pengaruh terhadap kestabilan warna. Hal tersebut menunjukkan reaksi pencokelatan pada minuman teh dapat dihambat dengan penambahan fosfat pada kondisi $\mathrm{pH}<4,0$. Selain itu, penambahan SAPP $1300 \mathrm{mg} / \mathrm{L}$ dan asam fosfat $500 \mathrm{mg} / \mathrm{L}$ pada air pengekstrak dapat meningkatkan konsentrasi tanin hingga 29,8\% dibandingkan ekstraksi tanpa fosfat. Hal tersebut dapat memberikan manfaat bagi industri sebagai potensi penghematan biaya dalam proses ekstraksi teh, dengan mempertimbangkan aspek sensori yang dihasilkan.

\section{DAFTAR PUSTAKA}

Achyadi N, Sutrisno A, Fauziah A. 2018. Pengaruh bahan pengekstrak terhadap karakteristik ekstrak senyawa fungsional dari kulit buah naga merah (Hylocereus polyrhizus). Pas Food Technol J 4: 23-30. DOI: 10.23969/pftj.v6i1. 1505.
Ananingsih VK, Sharma A, Zhou W. 2013. Green tea catechins during food processing and storage: $A$ review on stability and detection. Food Res Int 50: 469-479. DOI: 10.1016/j.foodres. 2011.03.004.

Baek N, Kim Y, Duncan SE, Leitch K, O'Keefe S. 2021. (-)-Epigallocatechin gallate stability in ready-to-drink ( $\mathrm{rtd}$ ) green tea infusions in $\mathrm{TiO} 2$ and oleic-acid-modified $\mathrm{TiO} 2$ polylactic acid film packaging stored under fluorescent light during refrigerated storage at $4^{\circ} \mathrm{C}$. Foods 10: 1-12. DOI: 10.3390/foods100 40723.

Balittri J. 2013. Kandungan senyawa kimia pada daun teh (Camellia sinensis). War Penelit dan Pengemb Tanam Ind 19: 12-16.

Bark KM, Yeom JE, Yang JI, Yang IJ, Park CH, Park HR. 2011. Spectroscopic studies on the oxidation of catechin in aqueous solution. Bull Korean Chem Soc 32: 3443-3447. DOI: 10.5012/ bkcs.2011.32.9.3443.

Bijlsma J, de Bruijn WJC, Hageman JA, Goos P, Velikov KP, Vincken JP. 2020. Revealing the main factors and two-way interactions contributing to food discolouration caused by ironcatechol complexation. Sci Rep 10: 1-11. DOI: 10.1038/s41598-020-65171-1.

[BPOM RI] Badan Pengawas Obat dan Makanan Republik Indonesia. 2019. Perka BPOM No. 11 Tahun 2019 tentang Batas Maksimum Penggunaan Bahan Tambahan Pangan. BPOM RI, Jakarta.

Briawan D, Hardinsyah, Marhamah, Zulaikhah, Aries M. 2011. Konsumsi minuman dan preferensinya pada remaja di Jakarta dan Bandung. Gizi Indon 34: 43-51. DOI: 10.36457/gizindo.v34i1. 100.

Boyd CE, Tucker CS, Somridhivej B. 2016. Alkalinity and hardness: Critical but elusive concepts in aquaculture. J World Aquac Soc 47: 6-41. DOI: 10.1111/jwas.12241.

Chan EWC, Soh EY, Tie PP, Law YP. 2011. Antioxidant and antibacterial properties of green, black, and herbal teas of Camellia sinensis. Pharmacognosy Res 3: 266-272. DOI: 10.4103/ 0974-8490.89748.

Chen Z, Zhu Q, Tsang D, Huang Y. 2001. Degradation of green tea catechins in tea drinks. J Agric Food Chem 49: 477-482. DOI: 10.1021/ jf000877h.

Chen L, Wang W, Zhang J, Wang W, Ni D, Jiang $H$. 2020. Dehydroascorbic acid affects the stability of catechins by forming conjunctions. Molecules 25: 1-12. DOI: 10.3390/molecules25184076. 
Chaturvedula VSP, Prakash I. 2011. The aroma, taste, color and bioactive constituents of tea. $J$ Med Plants Res 5: 2110-2124.

Choung M, Lee M. 2011. Optimal extraction conditions for simultaneous determination of catechins and caffeine in green tea leaves. Food Sci Biotechnol 20: 327-333. DOI: 10.1007/s100 68-011-0046-1.

Corral FM, Oliveira PG, Pereira AG, Lopes CL, Lopez CJ, Prieto MA, Gandara JS. 2020. Technological application of tannin-based extracts. Molecules 25: 1-27. DOI: 10.3390/molecules 25030614.

Dai Q, He Y, Ho C, Wang J, Wang S, Yang Y, Gao L, Xia T. 2017. Effect of interaction of epigallocatechin gallate and flavonols on color alteration of simulative green tea infusion after thermal treatment. J Food Sci Technol 54: 2919-2928. DOI: 10.1007/s13197-017-2730-5.

Dolińska B, Ostróżka-Cieślik A, Caban A, Rimantas K, Leszczyńska L, Ryszka F. 2012. Influence of trace elements on stabilization of aqueous solutions of ascorbic acid. Biol Trace Elem Res 150: 509-512. DOI: 10.1007/s12011-012-95244.

Du J, Cullen JJ, Buettner GR. 2012. Ascorbic acid: Chemistry, biology and the treatment of cancer. Biochim Biophys Acta-Rev Cancer 1826: 443457. DOI: 10.1016/j.bbcan.2012.06.003.

Ellinger R. 2018. Phosphates as Food Ingredients. 15. 85-87. CRC Press, Boca Raton, Florida.

[FAO] Food Agricultural Organization. 2019. GSFA Online : Sodium Polyphosphate (452i).: http://w ww.fao.org/gsfaonline/additives/details.html?id= 37 [13 September 2019].

Fan FY, Shi M, Nie Y, Zhao Y, Ye JH, Liang YR. 2015. Differential behaviors of tea catechins under thermal processing: formation of nonenzymatic oligomers. Food Chem 106: $347-$ 354. DOI: 10.1016/j.foodchem.2015.09.056.

Forester S, Lambert J. 2011. The role of antioxidant versus pro-oxidant effects of green tea polyphenols in cancer prevention. Mol Nutr Food Res 55: 844-854. DOI: 10.1002/mnfr.2010006 41.

Gadkari PV, Balaraman M. 2015. Catechins: sources, extraction and encapsulation - a review. Food Bioprod Process 93: 122-138. DOI: 10.1016/j.fbp.2013.12.004.

Hariyadi P. 2013. Hot-fill processing of beverages. Foodreview Int 1: 46-49.

Hasan A. 2017. Pengaruh asam askorbat dan sodium acid pyrophosphate (sapp) dalam mencegah kerusakan antioksidan ubijalar ungu varietas antin 3. J Agritech Sci 1: 38-50.
Huang W, Lin Y, Ho R, Liu H, Lin Y. 2013. Effects of water solutions on extracting green tea leaves. Sci World J 2013: 1-6. DOI: 10.1155/2013/ 368350.

Hunaefi D, Yuliana ND, Rynaldo M, Dede R. 2018. Emotional sensory mapping of PET-packaging tea product. Int Conf Food Agric (2018): 288305.

Iwasa K. 1975. Methods of chemical analysis. Japan Agric Res Q 9: 161-164.

Jiang L, Tu Y, Li X, Li H. 2018. Application of reverse osmosis in purifying drinking water. E3S Web of Conferences 38: 1-6. DOI: 10.1051/e3s conf/20183801037.

Karseno, Erminawati, Yanto T, Setyowati R, Haryanti $\mathrm{P}$. 2017. Effect of $\mathrm{pH}$ and temperature on browning intensity of coconut sugar and its antioxidant activity. Food Res 2: 1-7. DOI: 10.26656/fr.2017.2(1).175.

[Kemendag RI] Kementerian perdagangan Republik Indonesia. 2015. What's inside indonesian tea. Export News Indonesia 2: 1-12.

Kortei NK, Odamtten GT, Obodai M, Appiah V, Akonor PT. 2015. Determination of color parameters of gamma irradiated fresh and dried mushrooms during storage. Croat $\mathrm{J}$ Food Technol Biotechnol Nutr 10: 66-71.

Kim Y, Welt B, Talcott S. 2011. The impact of packaging materials on the antioxidant phytochemical stability of aqueous infusions of green tea (Camellia sinensis) and Yaupon Holly (llex vomitoria) during cold storage. J Agric Food Chem 59: 4676-4683. DOI: 10.1021/jf104799y.

Li N, Taylor L, Ferruzzi M, Mauer L. 2012. Kinetic study of catechin stability: Effects of $\mathrm{pH}$, concentration, and temperature. J Agric Food Chem 60: 12531-12539. DOI: 10.1021/jf3041 $16 \mathrm{~s}$.

Lin ZH, Qi YP, Chen RB, Zhang FZ, Chen LS. 2012. Effects of phosphorus supply on the quality of green tea. Food Chem 130: 908-914. DOI: 10.1016/j.foodchem.2011.08.008.

Liu P, Lu X, Li N, Zheng Z, Qiao X. 2019. Characterization, variables, and antioxidant activity of the maillard reaction in a fructose-histidine model system. Molecules 24: 1-15. DOI: 10.3390/molecules24010056.

Lončarić A, Pablo Lamas J, Guerra E, Kopjar M, Lores M. 2017. Thermal stability of catechin and epicatechin upon disaccharides addition. Int J Food Sci Technol 53: 1195-1202. DOI: 10.1111/ijfs. 13696 .

McHugh ML. 2011. Multiple comparison analysis testing in anova. Biochemia Medica 21: 203209. DOI: 10.11613/bm.2011.029. 
Nagai H, Sato K. 2001. Asahi Soft Drinks Co. Ltd. 2001 Maret 13. Method for preventing powdered tea-containing food from browning and powder green tea beverage to prevent browning held in transparent container. Paten JP2001061412A.

Orona V, Medina G. 2019. Changes in phenolics and antioxidant capacity during short storage of ready-to-drink green tea (Camellia sinensis) beverage at commercial conditions. Post Harvest Technol 78: 141-145. DOI: 10.1590/ 1678-4499.2018027.

Muzolf-Panek M, Gliszczyńska-Świgło A, Szymusiak $\mathrm{H}$, Tyrakowska B. 2012. The influence of stereochemistry on the antioxidant properties of catechin epimers. Eur Food Res Technol 235: 1001-1009. DOI: 10.1007/s00217-012-1826-4.

Pastoriza S, Mesías M, Cabrera C, Henares JAR. 2017. Healthy properties of green and white teas: An update. Food Funct 8: 2650-2662. DOI: $10.1039 / \mathrm{c} 7 \mathrm{fo} 00611 \mathrm{j}$.

Spiro M, Price WE. 1987. Kinetics and equilibria of tea infusion part 6: The effects of salts and of $\mathrm{pH}$ on the concentrations and partition constants of theaflavins and caffeine in Kapchorua Pekoe fannings. Food Chem 24: 51-61. DOI: 10.1016/0308-8146(87)90083-5.

Tsao R, Li H. 2012. Antioxidant properties in vitro and in vivo: realistic assessments of efficacy of plant extracts. CAB Rev 7: 1-9. DOI: 10.1079/ PAVSNNR20127009.

Vuong Q, Golding J, Stathopoulos C, Roach P. 2013. Effects of aqueous brewing solution $\mathrm{pH}$ on the extraction of the major green tea constituents. Food Res Int 53: 713-719. DOI: 10. 1016/j.foodres.2012.09.017.
Wang L, Kim D, Park J, Lee C. 2003. Various antibrowning agents and green tea extract during processing and storage. J Food Process Preserv 27: 213-225. DOI: 10.1111/j.17454549.2003.tb00513.x.

Xu H, Zhang L, Chenxin E. 2010. The Coca Cola Company. 2010 Mei 6. Inhibition of the formation of tea opacification or precipitation in tea drinks during storage. Paten USA 20100035098 A1.

Xu Y, Zou C, Gao Y, Chen J, Wang F, Chen G, Yin J. 2016. Effect of the type of brewing water on the chemical composition, sensory quality and antioxidant capacity of Chinese teas. Food Chem 236: 142-151. DOI: 10.1016/j.foodchem. 2016.11.110.

Yeni G, Syamsu K, Mardliyati E, Muchtar H. 2017. Determination of process technology on making of pure gambier and standardized catechin from raw gambier. J Litbang Ind 7: 1-10.

Zeng L, Maa M, Li C, Luo L. 2016. Stability of tea polyphenols solution with different $\mathrm{pH}$ at different temperatures. Int J Food Prop 20: 118. DOI: $10.1080 / 10942912$. 2014.983605.

Zhang $\mathrm{H}$, Jiang $\mathrm{Y}$, Lv $\mathrm{Y}$, Pan J, Duan $\mathrm{Y}$, Huang $\mathrm{Y}$, Zhu Y, Zhang S, Geng K. 2017. Effect of water quality on the main components in Fuding white tea infusions. J Food Sci Technol 54: 12061211. DOI: 10.1007/s13197-017-2571-2.

Zimmermann B, Gleichenhagen M. 2011. The effect of ascorbic acid, citric acid and low $\mathrm{pH}$ on the extraction of green tea: How to get most out of it. Food Chem 124: 1543-1548. DOI: 10.1016/j. foodchem.2010.08.009. 